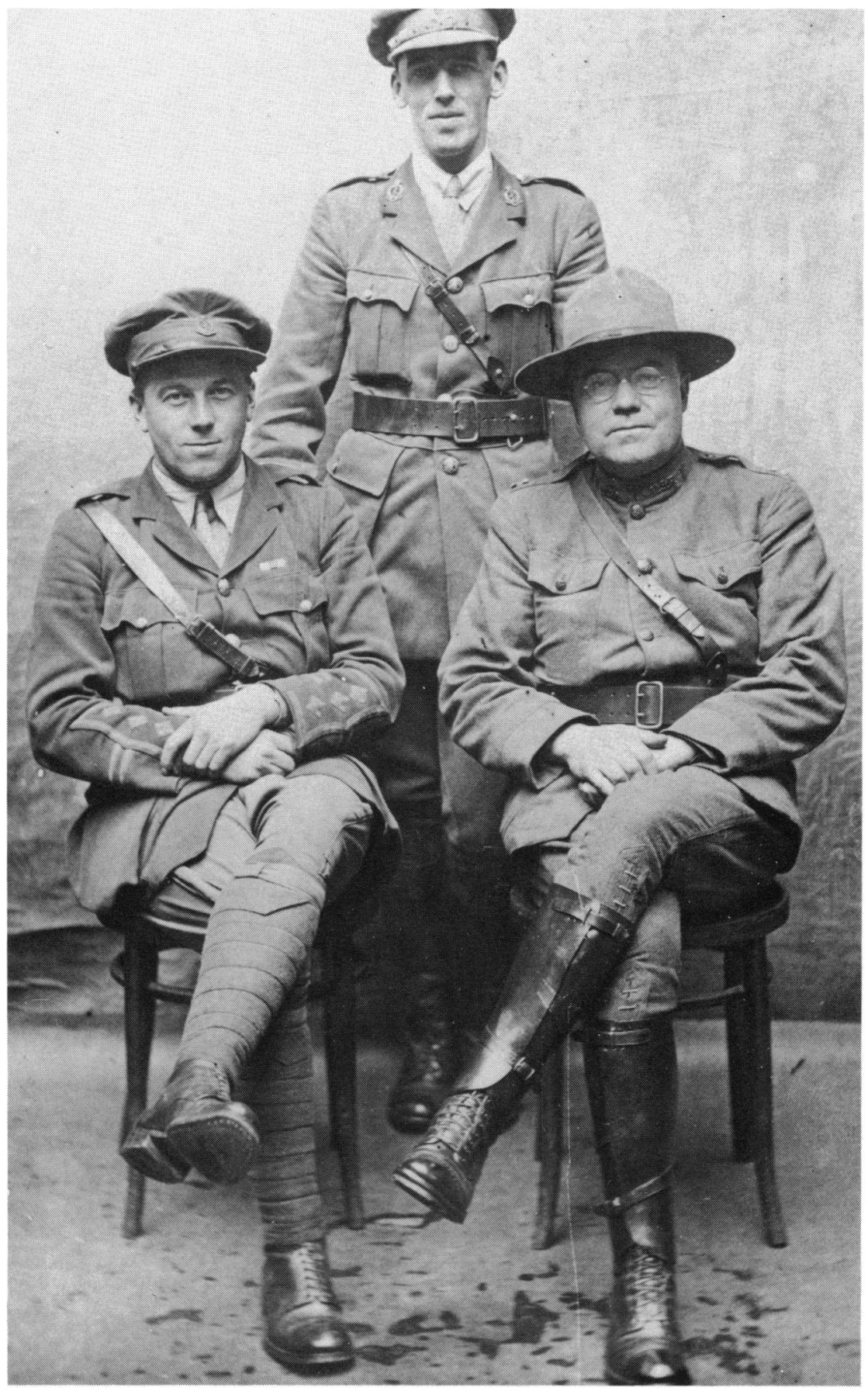

From left to right, Captains John Fraser and A. N. Hooper, Royal Army Medical Corps, and Captain Walter B. Cannon, U.S. Army Medical Service, at Casualty Clearing Station No. 33, Béthune, October 1917. (From the Cannon Papers, Countway Library of Medicine, Boston.) 


\title{
WALTER B. CANNON AND THE MYSTERY OF SHOCK: A STUDY OF ANGLO-AMERICAN CO-OPERATION IN WORLD WAR I
}

\author{
by \\ SAUL BENISON, A. CLIFFORD BARGER, and ELIN L. WOLFE*
}

The hospital is on a gentle slope, whence one can see far out along the avenue down which we have come. It is all gay and golden. The earth lies there, still and smooth and secure; even fields are to be seen, little, brown, tilled strips, right close by the hospital. And when the wind blows away the stench of blood and of gangrene, one can smell the pungent ploughed earth. The distance is blue and everywhere peaceful, for from here the view is away from the Front.

-Erich Maria Remarque, Prologue to Der Weg Zurück (The Road Back), 1931

The autumn of 1914 marked the beginning of an extraordinary transformation of the plains of northern France and Flanders. Fields where farmers had for centuries ploughed with horses, laid down seed, and set out livestock to graze in an effort to sustain life, in a relatively brief period of time became a maiming and killing ground for British, French and German armies. At first, combatants on both sides believed the conflict would be a short one, crowned by a quick victory. Within months, that illusion was shattered by an unplanned strategy of positional warfare which featured miles of trenches protected by barbed wire and the massed firepower of rifles, mortars, machine guns, and artillery. ${ }^{1}$ Such warfare not only prolonged the duration of the fighting, it also exacted a frightful toll of casualties. No one was prepared for this situation, least of all the military surgeons, who often had to deal with burgeoning problems far beyond their understanding and skill. In 1915, British surgeons in Flanders became aware that in addition to the alarming number of severely lacerated and contaminated wounds they saw day after day, more and more of the soldiers who came to them for care mysteriously died of shock. It was not an unknown condition.

* Saul Benison, Ph.D., A. Clifford Barger, MD, and Elin L. Wolfe, M.L.S., Walter B. Cannon Research Project, Francis A. Countway Library of Medicine, 10 Shattuck Street, Boston, MA 02115, USA

The account that appears above is derived from research for the second volume of Cannon's biography, now in process. (See Walter B. Cannon: the life and times of a young scientist: op. cit., note 2 below.) Unpublished materials cited, unless otherwise noted, are in the Cannon Papers which are located in the Countway Library of Medicine and have been fully inventoried.

${ }^{1}$ See, e.g., L. L. Farrar, Jr., The short war illusion, Santa Barbara, Cal., Cleo Press, 1973; Peter Parmet, ed., Makers of modern strategy, 2nd ed., Princeton University Press, 1986, especially the contributions of Gunther E. Rothenberg, Michael Howard, and Michael Geyer. See also the chapter on 'Firearms and projectiles: their bearing on wound production', in The Medical Department of the United States Army in the World War, vol. 11, Surgery, Washington, D.C., Government Printing Office, 1927, pp. 9-56. 


\section{Saul Benison, A. Clifford Barger, and Elin L. Wolfe}

Ambrose Paré, the distinguished French military surgeon, had described some of its major symptoms more than three hundred years before. Yet despite the advances of medical science and surgery by the early twentieth century, the cause and onset of shock remained as much of a mystery as it had been for Paré. Late in 1916, British medical officers in the field, increasingly baffled and frustrated by the deadly condition, joined with medical scientists in England to undertake an investigation of the problem. Nor were the British alone in their concern. Several months before, the Rockefeller Foundation had invited Walter B. Cannon at the Harvard Medical School to undertake an experimental study of shock in France in conjunction with the surgeon Alexis Carrel. Cannon was unable to accept the invitation. The problem, he explained, was so complex that he felt he could do little that would be of immediate use. But when the National Research Council later asked Cannon if he would establish a physiological committee to develop research programmes to maintain the health and safety of the armed forces, Cannon in a turn-around made the study of shock one of the committee's priorities. While most members of the committee devoted themselves to seeking the cause of shock, Cannon for his part began a search for a therapy that might reduce its mortality. ${ }^{2}$

To begin with, Cannon immersed himself in the literature that had accumulated on shock. Still, for all of his ardour in preparation, he lacked one element, which basically affected his understanding of the problem. Cannon had never examined or treated a human patient in shock. Some of those in the United States who had preceded him in this research, chief among them George Crile of Cleveland, had extensive clinical experience with shock. Before World War I Crile, a surgeon, had seen and treated numerous patients in shock (many of them victims of industrial or transport accidents). ${ }^{3}$ Cannon, on the other hand, was dependent for his understanding of the onset and development of shock on the clinical descriptions left by other surgeons and physicians.

One description that initially caught his attention was that made by Hermann Fischer in a presentation to a surgical clinic in Breslau in 1870. Fischer, who had been trained by Bernard Langenbeck, a notable German military surgeon, was well known to those interested in problems of shock. Of particular value was his descriptionsetting out in some detail the major elements of shock - of a patient who was injured by the pole of a carriage drawn by runaway horses. "He lies perfectly quiet," Fischer began, "and pays no attention whatever to events about him. The pupils are dilated and react slowly to light. He stares purposelessly and apathetically straight before him.

\footnotetext{
${ }^{2}$ For Paré on shock, see Thomas Johnson, tr., The collected works of Ambroise Paré, London, 1634; repr. Pound Ridge, N.Y., Milford House, 1968, p. 334. For a good summary history of the shock problem, see Carl J. Wiggers, Physiology of shock, New York, Commonwealth Fund, 1950, pp. 1-20. When Cannon initially turned down the offer to work on shock, the Rockefeller Foundation approached his colleague at Harvard, William T. Porter, who promptly agreed to serve with Carrel. For details concerning the formation of the National Research Council Physiological Committee, see Saul Benison, A. Clifford Barger, and Elin L. Wolfe, Walter B. Cannon: The life and times of a young scientist, Belknap Press of Harvard University Press, 1987, pp. 388-9.

${ }^{3}$ See G. W. Crile, An experimental research into surgical shock, Philadelphia, Lippincott, 1899; see also Peter C. English, Shock, physiological surgery, and George Washington Crile: medical innovation in the progressive era, Westport, Conn., Greenwood Press, 1980.
} 
His skin and such parts of the mucous membranes as are visible are as pale as marble, and his hands and lips have a bluish tinge. Large drops of sweat hang on his forehead and eyebrows, his whole body feels cold to the hand ... Sensibility is much blunted over the whole body ... If the limbs are lifted and then let go, they immediately fall as if dead ... The pulse is almost imperceptible and very rapid ... The patient is conscious, but replies slowly and only when repeatedly and importunely questioned ... His respiration is characterized by long, deep, sighing inspirations, alternating with very superficial ones, which are scarcely visible or audible." 4

Fischer's description set the agenda for Cannon's research. From the beginning, Cannon decided that if he were to make any headway, he would have to determine the primary and secondary features of shock from the multiplicity of signs and symptoms detailed by Fischer. Second, and no less important, he would have to salvage from extant theories of the cause of shock an approach that might serve him as a guide in his investigations. There were a number of notable theories from which to choose.

During the American Civil War, S. Weir Mitchell, with the assistance of George Morehouse and William W. Keen, after studying wounded Union soldiers in shock, came to the conclusion that their condition was due to a paralysis or an exhaustion of nerve force. Such an exhaustion, they asserted, could affect one or more nerve centres and, if severe enough, might under certain conditions produce a paralysis of sensation or motion. ${ }^{5}$ More than a generation later, George Crile also suggested that the cause of shock might be due to an exhaustion of nerve force; his rationale, however, was far more complex than that advanced by Mitchell and his colleagues. From the outset of his animal experiments, Crile focused on the vascular system and in particular on directly measured arterial blood pressure. The decrease of vasoconstrictor tone in shock, he maintained, allowed the blood to accumulate and stagnate in the veins of the splanchnic bed, and it was this stagnation that brought on the various effects seen in shock. ${ }^{6}$ His notion that exhaustion of vasomotor centres was a primary factor in shock was promptly criticized by physiologists.

In fact, physiologists were especially vigorous in advancing their own theories. William T. Porter at Harvard, following his early research on shock, energetically maintained that fat embolism was its cause. Yandell Henderson at Yale, on the other hand, suggested that shock was due to a decrease of venous return to the heart, a condition he attributed to a loss of carbon dioxide brought on by an excessive overventilation of the lungs. At the other end of the spectrum, Samuel J. Meltzer, widely acknowledged as one of the deans of physiology in the United States, instead of focusing exclusively on disturbances of circulation, argued that the functions of the

\footnotetext{
${ }^{4}$ Hermann Fischer, 'Über den Shok', Samml. klinischer Vortr., 1870, 1: 69-82; see also Fischer, 'Remarks on shock', St Louis med. surg. J., 1875, 12, n.s. no. 2: 68-78. John Collins Warren adopted Fischer's description and discussions of shock for use in his textbook, Surgical pathology and therapeutics, Philadelphia, Saunders, 1895, p. 278. Cannon gave an abbreviated account of Fischer's description in his Shattuck Lecture, 'The physiological factors concerned in surgical shock', Boston med. surg. J., 1917, 176: 859-67; see esp. pp. 859-60.

${ }^{5}$ S. Weir Mitchell, George R. Morehouse, and William W. Keen, Reflex paralysis, Circular No. 6, Surgeon General's Office, 10 March 1864; idem, Gunshot wounds and other injuries of nerves, Philadelphia, Lippincott, 1864.

${ }^{6}$ See, e.g., G. W. Crile, Blood pressure in surgery, Philadelphia, Lippincott, 1903, pp. 401-2.
} 
body were supported on a dual principle of well-balanced antagonism between excitation and inhibition and that injuries which produced shock disturbed equilibrium "favouring the development of the inhibitory side of all the functions of the body". ${ }^{7}$

Cannon, faced with the necessity of developing a research programme that would further the quest for an effective therapy against shock, and reluctant to adopt any of the current theories proposed by other physiologists as to its cause, came to believe that a failure in the circulation of blood was central to the development of shock. ${ }^{8}$ Like Crile before him, he accepted the notion that the blood in a patient in shock pooled in the splanchnic bed, whose capacity was so ample that it was possible for a person to bleed to death into his own splanchnic vessels. He could not, however, accept Crile's notion of vasomotor exhaustion as the cause of circulatory failure, for there was clear experimental evidence that the vasomotor reflexes were still responsive in shock. The evidence left Cannon, as it had others, with a puzzle. What prevented blood in the splanchnic area from returning to the general circulation?

Investigators before Cannon had devised a variety of strategies to improve the circulation in shock. Some, in an effort to increase blood pressure, had injected warm saline solutions into the veins, with only transient improvement. Others had introduced adrenalin into the veins and found it counter-productive; on the one hand, it contracted splanchnic arterioles, but, on the other, it dilated arterioles elsewhere. Cannon, for his part, focused his attention on the splanchnic portal area. Here, he reasoned, blood flowed between two capillary beds: one, the capillaries of the stomach, spleen, pancreas, and intestines, from which blood entered the mesenteric branches of the portal vein; and the other, the capillaries of the liver, through which blood must flow before reaching the inferior vena cava. Since the portal vein and its various branches have smooth muscle in their walls, it appeared to him that the application of a constrictor agent to the walls of the veins might well supply the motive force to move the stagnant blood forward. Instead of injecting such an agent into the veins, he believed that it might be better to inject it into the abdomen to increase smooth muscle tone, and after some animal experiments, he decided to use pituitrin as his constricting agent. ${ }^{9}$

Cannon was so encouraged by the promise of these early experiments that soon after the United States entered the war in April 1917, he joined Harvard Base Hospital No. 5

\footnotetext{
${ }^{7}$ S. J. Meltzer, 'The nature of shock', Archs internal med., 1908, 1: 571-88, esp. p. 588; W. T. Porter, 'Fat embolism as a cause of shock', Boston med. surg. J., 1917, 176: 248; Yandell Henderson, 'Acapnia and shock', Am. J. Physiol., esp. 1908, 21: 126-56 and 1910, 27: 152-76. Cannon believed that Henderson was mistaken in proposing that shock was due to acapnia, and that the shock-like effect Henderson saw experimentally was due to mechanical obstruction of return of blood to the heart and the consequent failure of circulation. For the detail of Cannon's reasoning, see further his paper, 'A consideration of the nature of wound shock', in Investigation of the nature and treatment of wound shock and allied conditions, Report No. II, Special Investigation Committee on Surgical Shock and Allied Conditions of the MRC, 25 December 1917, pp. 108-11.

${ }^{8}$ Cannon, op. cit., note 4 above, p. 864.

${ }^{9}$ Ibid., pp. 866-7. Cannon's Shattuck Lecture lacks references, but among the more recent literature he may have consulted were the articles by C. A. Hill, 'Report on the use of pituitary extract (pituitrin) in surgical shock', Boston med. surg. J., 1913, 168: 720-2, and by J. D. Mortimer, 'Should vaso-constrictors (adrenalin, pituitrin) be used in emergencies, especially surgical shock?', in The Practitioner (London), Jan.-Jun. 1915, pp. 867-71.
} 


\section{Walter B. Cannon and the mystery of shock}

with an understanding that he would be allowed to go to the front-line trenches to carry on his research on soldiers in shock. "I do not wish to elaborate at the present time," he wrote in an essay before leaving for Europe, "on the possibility of using pituitrin ... in shock cases... But before anything definite and practical can be made of this suggestion, it must be tested out carefully on a considerable scale. This I hope to do in the course of future work, and if favourable results arise from these tests, I shall report on them." 10

From the moment the Harvard Hospital Unit arrived in London, Cannon found himself in a round of seemingly endless activities arranged by the British medical establishment-meeting political and scientific notables, attending meetings of the Royal Society, and visiting the headquarters of the Medical Research Committee (MRC), where he heard first-hand reports of the progress of the Committee's various investigations into shock and its allied conditions. ${ }^{11}$ The fact that some of these were conducted in France encouraged Cannon to think that the Committee might help him carry on his research with a British unit at the front. When he later learned from a conversation with Walter Fletcher, the secretary of the MRC, that his old friend T. R. Elliott was serving as a consultant on medical research with the British Army in France, his hopes for such a collaboration soared. ${ }^{12} \mathrm{He}$ could hardly wait to get to France.

For all his anticipation, Cannon found his early experiences in France depressing. Base Hospital No. 5, sent to relieve British Base Hospital No. 11 at Camiers, was well behind the front lines. The encampment-actually a tent city spread over acres of sandy dunes and sump pits-had few laboratory facilities. "It is hopeless", Cannon complained in a letter home soon after arriving at Camiers, "to attempt to do any experimental work ... instruments ... cannot be obtained. Animals are hard to get. And the laboratory is so small that almost any work that is done specially interferes with the necessary routine." 13 Worse, unable to make contact with Elliott, he had to content himself with a pledge from Colonel Cuthbert Wallace, surgical consultant to the British First Army, that he would try to arrange a transfer for Cannon to a British

\footnotetext{
${ }^{10}$ Cannon, op. cit., note 4 above, p. 866. Cannon began his enlistment in the U.S. Army Medical Service with the rank of First Lieutenant and ended as a Lieutenant-Colonel when he was discharged in 1919. Harvey Cushing, the organizer and director of Harvard Base Hospital No. 5, wrote at length about his experiences in World War I. See Cushing, From a surgeon's journal, 1915-1918, Boston, Little, Brown, 1936; see also The story of U.S. Army Base Hospital No. 5, Cambridge, Mass., The University Press, 1919.

${ }^{11}$ The Third Annual Report of the Medical Research Committee, 1916-17, gives the background for the Committee's concern with shock as a subject of inquiry (pp. 77-9). See also 'Memorandum upon surgical shock and some allied conditions, issued by the Medical Research Committee', Br. med. J., 24 March 1917, pp. 381-3. Prominent among the English investigators working on shock were the physiologists William M. Bayliss and Ernest H. Starling and the pharmacologist Henry H. Dale.

12 In the prewar years T. R. Elliott carried out physiological experiments that played a key role in elucidating the relationship between the adrenal glands and the sympathetic nervous system; see further Benison, Barger, and Wolfe, op. cit., note 2 above, esp. pp. 379-80, 469n.9, and 502n.64. Cannon's week in England, 23-30 May 1917, is documented in his diary for 1917-18 and in his letters to his wife Cornelia from London and Oxford. For the latter source, reference here is primarily to the bound volume of typed transcripts, 'Letters home from France and England, 1917-18' (hereafter cited as LH with the appropriate page numbers).

${ }^{3}$ LH, p. 38. For more on Camiers, see Cannon's diary notes for 1-25 June 1917; also Cushing, From a surgeon's journal, note 10 above, pp. 142-59.
} 
unit at the front. Frustrated that he could not begin his research at once, and oppressed by a feeling that he was of little value to the hospital, Cannon asked his friend Robert Osgood, chief of surgery, if he could assist in the operating room.

Cannon's offer could not have come at a more opportune time. Within a day, the first wounded from the British drive at Messines came pouring into the hospital. In the days that followed, Cannon assisted in operations, helped in the wards with dressings, worked in the discharge tent, and in one instance hypnotized a patient dumb from shell shock and helped him to speak. "In general," he wrote his wife Cornelia, "[I] got into action where there was need. It has been an immense reassurance of self-respect to be in service and actually desired, as I now am, for all sorts of uses. But it is not, as you will probably say at once, getting on with the work I came over to do." (LH, p. 38)

Despite the pride that Cannon took in tending the wounded and the opportunity provided for him to gain surgical experience, he became increasingly restive to do more than routine work. Several days later, his gloom lifted when an unexpected visit from T. R. Elliott brought support for his plan of going to a British unit at the front. And then to Cannon's delight, Elliott agreed with him that if circumstances later dictated the necessity for further experiments, he should go to London to continue his research in Bayliss's laboratory at University College - an idea that was promptly endorsed by a friendly letter from Bayliss. ${ }^{14}$

Anticipating that he would soon have an opportunity for testing the effect of pituitrin in improving circulation of blood in actual shock victims, Cannon visited a mortuary in a nearby village to see if he could use a blunt trocar for intra-abdominal injection of pituitrin without puncturing the intestines. The results proved promising. Nineteen punctures in the front of the abdomen had no effect on the intestines, he noted in his diary on $15 \mathrm{June}$; of six injections on the sides, only one entered the caecum and one the descending colon. At about the same time, he began a study with his former student Reginald Fitz on trench nephritis, which on its face had nothing to do with shock.

Fitz, who had worked for several years at the Rockefeller Institute with Donald Van Slyke applying techniques of physical chemistry to the study of diseases of the kidney and pancreas, had become interested in examining such matters as acid-base balance in the blood, respiratory gas exchange, and the transport of oxygen and carbon dioxide in the bloodstream. Equally important, he had become adept in the use of the Van Slyke apparatus for measuring oxygen and carbon dioxide content in blood. ${ }^{15}$ Fitz welcomed Cannon's help, but Cannon was equally well served by the collaboration. In one of his letters home, he later revealed that his purpose in working with Fitz was to learn how to use the Van Slyke apparatus. "I have long wished to know these methods, but have not had time to learn them," he wrote, "so that the advantage has not been wholly one-sided in our cooperation. There is another matter of interest in this connection, and that is the suggestion on the part of certain English investigators, who have

\footnotetext{
${ }^{14}$ LH, p. 42; see also T. R. Elliott to Cannon, with copy of Elliott to Cuthbert Wallace, both 15 June 1917, and W. M. Bayliss to Cannon, 16 June 1917.

${ }^{15}$ For Cannon's earlier relations with Fitz as a student, see Benison, Barger, and Wolfe, op. cit., note 2 above, p. 325. For a description of Van Slyke's laboratory, see G. W. Corner, A history of the Rockefeller Institute, 1901-1953, New York, Rockefeller Institute Press, 1964, pp. 274-7.
} 


\section{Walter B. Cannon and the mystery of shock}

recently reported that they find in experimental shock conditions which might be caused by blood changes - such blood changes as we have been studying. It may be necessary, therefore, or possible to continue these studies if I ever get into relation with shock cases in human beings." (LH, p. 48)

On 24 June 1917, Cannon received word that Elliott and Wallace had arranged for him to work for three weeks at British Casualty Clearing Station (C.C.S.) No. 33 at Béthune. Realizing the need for a supply of physiological instruments to carry his research forward, he went to one of his friends, Captain C. G. L. Wolf, at the British Hygiene Laboratories at Boulogne and borrowed a viscometer, a colorimeter, and a Van Slyke apparatus. ${ }^{16}$

Colonel Wallace's selection of this particular clearing station as headquarters for Cannon's investigation of shock was hardly haphazard. Its senior surgeon, Captain John Fraser, a graduate of the University of Edinburgh Medical School, was deeply interested in the problem of shock. Moreover, C.C.S. No. 33 generally received the most serious cases of shock in that area of the front, thus affording Cannon a unique environment in which to carry on his research. ${ }^{17}$ Upon his arrival at Béthune, Wallace promptly took Cannon on a tour of various aid and casualty clearing stations so that he might meet some of the surgeons in the area and, in particular, Captain Ernest Cowell, chief surgeon of C.C.S. No. 23, who several months before had started a clinical investigation of the onset of shock.

Cowell, a graduate of University College Hospital in London, devoted himself essentially to unravelling the natural history of shock. Armed with clinical experience, a sphygmomanometer, and a stethoscope, he initially recorded the systolic and diastolic pressures of soldiers in rear areas living under relatively normal conditions, then compared the values with those of soldiers in front-line trenches living in an environment of fear and anxiety with lack of food, water, and sleep, and finally compared both with those taken in wounded soldiers in shock.

Cowell's study of the onset of shock had a number of important findings, not the least that it established parameters for the normal limits of blood pressure found in fighting men, as well as indices for measuring the seriousness of the fall in blood pressure often found in shock victims. Perhaps more important, it allowed him to illustrate for surgeons in the field the various ways that shock might appear. First, it might appear as primary shock, where soldiers after being wounded showed immediate symptoms of shock with a low blood pressure. Or it might appear as secondary shock, where a soldier who was wounded would, on first examination, have a normal blood pressure and wounds that appeared trivial and yet, several hours after being sent to the rear (with little attention paid to his needs for food, water, or

\footnotetext{
${ }^{16}$ LH, pp. 46, 49, 52; diary entries for 24 and 25 June 1917. Charles George Lewis Wolf was a Canadian whom Cannon had known when he was in the department of physiological chemistry at Cornell. Wolf spent part of the war with F. G. Hopkins at Cambridge University and remained there for the rest of his career.

17 John Fraser, later Regius Professor of Clinical Surgery at Edinburgh, was already well-known for his classic study, Tuberculosis in the bones and joints in children, New York, Macmillan, 1914. He and Cuthbert Wallace wrote a book about their experiences in the war, published as Surgery at a casualty clearing station, London, A. \& C. Black, 1918.
} 
warmth), would have a very rapidly falling blood pressure and shock that was pernicious and uncontrollable. ${ }^{18}$

Taking blood pressure, which today seems natural and easy, was, save for some well-trained physicians and surgeons like Harvey Cushing and George Crile, an uncommon procedure in the United States at the beginning of the twentieth century. In 1903, when Cushing tried to persuade surgeons at Harvard of the value of taking blood pressure by the Riva Rocci method during surgery, the surgeons of the hospitals affiliated with the medical school concluded that feeling the radial artery pulsation with a finger easily supplied all the blood pressure information they needed. ${ }^{19}$ Cannon was in little better position. Although his laboratory syllabus in physiology before World War I introduced students to the method that Carl Ludwig had used for directly measuring blood pressure in anaesthetized animals and to the oscillatory sphygmomanometer devised by Joseph Erlanger to estimate blood pressure in man, he emphasized the importance of feeling the radial pulse "for finding the rate of heart beat [in man] and for judging roughly the state of circulation in the arterial system". ${ }^{20}$

Actually, prior to his visit to Casualty Clearing Station No. 23, Cannon had no previous experience with the palpatory or auscultatory methods of measuring blood pressure then being used by British surgeons in their study of hypotension and shock. Although he had previously spent more than three weeks at Camiers and saw scores of wounded soldiers, he saw them at several removes in time and distance from the front and never had occasion to examine any cases of shock. His first opportunity to deal with patients in either primary or secondary shock occurred during his visit with Cowell when soldiers from the battle of Lens came streaming into C.C.S. No. 23. When a gravely injured German soldier with a big hole in his chest and suffering from shock with low blood pressure came to the operating room, Cannon asked Cowell for permission to inject the patient intraperitoneally with pituitrin in the hope of raising his pressure. Despite the injection, the soldier died several hours later. After autopsy, Cannon learned two things from Cowell that changed the direction of his research: first, that his injection had not harmed the intestines; second, and more important, that there was no pooling of blood in the splanchnic bed of patients in shock. ${ }^{21}$

The latter observation was not new for Cowell. British surgeons in the field who had operated on wounded soldiers had long known that there was no excess of blood in the splanchnic veins of their shocked patients. Cannon and other physiologists had been led astray by the engorged veins they had seen in the abdomens of their shocked experimental animals and assumed the blood that had been lost from the general

\footnotetext{
${ }^{18}$ See further E. M. Cowell, 'The initiation of wound shock', in Investigation, note 7 above, pp. 58-66. Cowell also served in World War II, rising to the rank of Major General as chief surgeon and director of medical services of the Allied Forces in North Africa.

${ }^{19}$ For the investigation of the importance of blood-pressure observations, see The Division of Surgery of the Medical School of Harvard University, Report of research work, 1903-1904, Bulletin no. II (March, 1904): 1-41. John Fulton tells the story in Harvey Cushing: a biography, Springfield, Ill., Thomas, 1946, pp. 213-15.

${ }^{20}$ Cannon, A laboratory course in physiology, 2nd ed., Harvard University Press, 1913, p. 97. Cannon's instructions for studying the flow and pressure of the blood are on pp. 81-100.

${ }^{21}$ Diary entries for 28, 29, and 30 June 1917.
} 


\section{Walter B. Cannon and the mystery of shock}

circulation stagnated in the splanchnics. ${ }^{22}$ Cowell's tutelage raised a new puzzle for Cannon. If the blood that had disappeared from the general circulation was not in the arteries or veins of the abdomen, where had it gone?

The very next day Cannon, utilizing the Van Slyke apparatus he had borrowed, began an examination of the blood of patients in shock as well as those suffering from gas gangrene infection and discovered that the blood in both cases had shifted toward the acid side-indeed, it appeared to him that the more marked the acidosis, the lower the blood pressure and the graver the shock. ${ }^{23}$

Stimulated by his observations of these cases as well as by what he had learned about shock from his stay with Cowell, Cannon on his return to Béthune asked Captain Fraser and another young surgeon, Captain A. N. Hooper, to join him in a study of the altered distribution of blood in cases of shock complicated by haemorrhage and gas gangrene. ${ }^{24}$ It was the implication of the acidosis in cases of gas gangrene and shock that particularly gripped him, and he promptly wrote home to share some of the excitement of the new turn in his research: "Fraser and I had a long talk about the cases of infection with the gas bacillus which I had become interested in at Cowell's place, and which were turning up here and going down to death with nothing done for them. I have been examining the blood of these men and finding that it is loaded with fixed acid. I have so free a hand, and the cases here are so desperate, that anything hopeful can properly be tried. So we are going ahead quite as we should go in an experimental study." (LH, pp. 63-4)

Colonel Wallace, who had previously undertaken an investigation of the relation of the toxaemia of gas gangrene and shock for the Medical Research Committee, was equally heartened by the turn in Cannon's research and he immediately asked Cannon's commanding officer to extend his tour of duty at Béthune. Walter Fletcher, on learning of the progress in Cannon's research, wrote him of the great satisfaction in England with the co-operative spirit he had shown at C.C.S. No. 23 and No. 33 and held out the possibility that Cannon, working together with Henry Dale and William Bayliss, might well in future solve the mystery of shock. ${ }^{25}$

The bestowal of such interest and praise gave Cannon momentary pause. Keenly aware of his lack of training in chemistry, he obliquely hinted to his wife of the need he had for a biochemist to help extend his research. "I wish that Lawrence Henderson were here", he wrote. "The condition of acidosis in the cases of gas infection is especially important, and he is a prime authority on the subject. If you are still in Cambridge, ask him to send me a reprint of his general discussion of the acid-base equilibrium in the blood."26

\footnotetext{
${ }^{22}$ For an expression of the view that accumulation of blood in the abdominal veins is not a feature of clinical shock, see Wallace and Fraser, Surgery at a casualty clearing station, note 17 above, p. 8.

${ }^{23}$ Diary entry for 3 July 1917 . Cannon later reported the results of his study in "Acidosis in cases of shock, haemorrhage and gas infection', in Investigation, note 7 above, pp. 47-60.

${ }^{24}$ This study eventuated in Cannon, Fraser, and Hooper, 'Some alterations in distribution and character of blood in shock and haemorrhage', in ibid., pp. 27-39.

${ }^{25}$ LH, pp. 64, 66-7; Walter Fletcher to Cannon, 27 June 1917.

${ }^{26}$ LH, p. 67. For more on L. J. Henderson, see Benison, Barger, and Wolfe, op. cit., note 2 above, especially pp. 125-8 and 391-2. For his publications on acid-base equilibrium, see the bibliography accompanying W. B. Cannon, 'Lawrence Joseph Henderson, 1878-1942', in Biographical memoirs, National Academy of Sciences, 1943, 23: 52-8.
} 


\section{Saul Benison, A. Clifford Barger, and Elin L. Wolfe}

Cannon began by devoting himself to the problem of sequestration of the blood in cases of shock, and he made careful measurements of the degree of acidosis, the concentration of haemoglobin, and the number of red cells in the venous and capillary blood of the wounded. In addition, he undertook a daily regimen of examining all incoming patients in shock, reading whatever papers on shock and gas gangrene were available, and, when time allowed, discussing his findings with his colleagues and visitors to C.C.S. No. $33 .{ }^{27}$

Some days into his new research, Cannon recorded an observation that suggested he was on the track of locating the blood lost in the circulation. "Read Bayliss", he noted in his diary, "and get ideas regarding effect of acid and cold on increasing blood viscosity so that it might stagnate in capillaries." Almost immediately, he became convinced that the "lost" blood was in fact located in the capillaries. "Up at one o'clock in morning", he wrote the next day, "... to examine a new case. Hooper and I study case together and find marked discrepancy between venous and capillary blood." He had found that in cases of low blood pressure, blood from the capillaries contained 2,000,000 more corpuscles per cubic millimetre than that taken from the arm veins at the same time-evidence of the leakage of plasma. ${ }^{28}$ The finding, he believed, was a breakthrough that would lead to a practical benefit. In mid-July he exultantly reported to Cornelia that he had found that acidosis was a major factor in shock:

All the evidence accumulated during the past week indicates that in shock and allied conditions a factor of first significance is the development of an acidosis. It would account for the discrepancy in the blood distribution mentioned earlier ... A patient in shock, with 41 volumes percent $\mathrm{CO}_{2}$ capacity in his blood, was taken to the operating room at 9:40 and subjected to a severe operation. The blood after the operation at 10:50, just 70 minutes after the first sample was taken, had a $\mathrm{CO}_{2}$ capacity of only 28 volumes percent-an astounding drop. Surgeons have reported that operating on shock cases is almost invariably fatal and have refused to do it. This looks like the secret of the trouble - and one that can be dealt with by very simple means. Only cooking soda is needed! Well, this is first enthusiasm, but certainly we have got new lines out that seem sure to bring important results. (LH, pp. 76-7)

In the weeks that followed, there were no new cases of shock at Béthune, and save for some random German shelling there was little action-a circumstance that permitted Cannon to review the data he had accumulated and discuss with Wallace, Fraser, and others his idea of using sodium bicarbonate to reverse the acidosis during operations on patients in shock. For the rest, as time allowed, he tried various ways to make sodium bicarbonate more palatable. It is clear that at this time he thought of introducing sodium bicarbonate to his patients by mouth. When he later prepared reports on the use of sodium bicarbonate in surgery, he gave credit to Sir Almroth Wright, who had previously used it to treat patients with acidosis accompanying gas gangrene infections. Cannon expanded on Wright's concept, however, noting that acidosis was not peculiar to the toxaemia produced by gas gangrene but rather was

${ }^{27}$ Diary entries for 6-10 July 1917.

${ }^{28}$ Diary entries for 11 and 12 July 1917; LH, p. 73. 


\section{Walter B. Cannon and the mystery of shock}

general for various states of low blood pressure, whether caused by haemorrhage or wounds without any apparent infection. In essence, the lesson he drew from Wright's work was that it was reasonable to treat shock with alkali, regardless of its pathogenesis. $^{29}$

A new British drive north of Ypres that began on 22 July gave Cannon an opportunity to carry his research forward. After a week of intense work tending the newly wounded in the operating room and on the wards, he described for his wife the circumstances that led to the application of his therapy and its initial results:

As I think I told you in the last letter, we decided to put our patients to practical test. Well, on Monday there was a patient with a blood pressure of 64 (the normal is about 120) millimetres of mercury and in a bad state. We gave him soda, a teaspoonful every two hours and the next morning the pressure was 130 . And on Wednesday a fellow came in with his whole upper arm in a pulp. Fraser said such cases usually die. At the end of the operation he had the incredibly low pressure of 50; soda was started at once and the next morning the pressure was 112. Both these cases. turned out very well. But they were not sufficiently decisive for me. I wanted a sure sign of the efficacy of the method. It came Friday night.

A poor fellow was brought in with terrible wounds-his left knee shattered, his right calf torn open, half of his right hand mashed and a ghastly rip in his right forearm. After the operation his blood pressure was 68 , his pulse was 148 , and his respiration 34 and over. About ten o'clock he was much worse. His respirations, which tell the tale of accumulating acid in the blood, had risen to more than 40 per minute. I urged that this was an emergency case and that radical treatment was necessary. We decided to inject the soda intravenously. When we went to him at 10:25 he was gasping for breath at the rate of 48 per minute, lifting himself on his elbow in spite of his wounds and crying in his gasps, "I can't breathe. Give me air. I can stick the pain but I must have air." We ran 35 ounces of the warm sodium bicarbonate solution into an arm vein. I never saw anything in my life so dramatic as the change that occurred. His respirations promptly fell from 48 to 26 per minute, and his pulse from 148 to 126 . And in ten minutes he was quietly sleeping. He had another similar crisis in the morning about 3:30 which was met similarly, and the next day his blood pressure rose $86,102,114$, and he sat slanting in his bed, smoking with much satisfaction a cigarette.

Two other cases, quite as decisive, though not so dramatic, testified to the efficacy of the treatment Friday night and Saturday morning. The unhappy thought is that $I$ have seen men die, and Fraser says he has seen hundreds of them die within a few hours or less after they have reached the stage from which we recovered these men. Fraser's great experience is a strong support, for he says that these men were literally "snatched from death"... when it was clear that the men were really secure, he declared, "This is a red letter day in my surgical experience." (LH, pp. 89-90)

Cornelia was ecstatic. "The wonder and joy of it", she replied, "doesn't grow less in reading the letter over and over ... Papa says he can't believe it, cooking soda is too simple! And I must say we all feel its incredible quality . . . to think that you were not in the least affected by your prepossessions for pituitrin, but began over again quietly

${ }^{29}$ Cannon, 'Acidosis in cases of shock', note 23 above, p. 58. For Wright's report on gas gangrene, see Lancet, 1917, i: $1-9$. 


\section{Saul Benison, A. Clifford Barger, and Elin L. Wolfe}

and modestly at the beginning, and in four weeks accomplished what the rest of them have been working on for years." 30

So remarkable did the early results of Cannon's experimental use of sodium bicarbonate appear that Colonel Wallace promptly forwarded a report of Cannon's work to the British General Headquarters to alert them to the promise of the new therapy for shock. ${ }^{31}$ Although Cannon was gratified by the reception given his research, he recognized that some of his insights needed further corroboration. Whereas he fully believed that the blood which "had disappeared" from the circulation in shock stagnated in the capillaries, he did not know whether capillary capacity was sufficient to contain so much blood. ${ }^{32}$ It was also evident that much still had to be learned about the relationship between low blood pressure and acidosis or the extent to which the oxygen-carrying capacity of the blood was reduced with increasing acidosis. There were other puzzles, and not the least, the very practical matter of what factors in a surgical operation might lead to increased acidosis.

The promise of Cannon's research caught the attention of the British Medical Research Committee as well. At the end of July, Bayliss was dispatched to Béthune so that he, in company with Cuthbert Wallace, T. R. Elliott, and C. G. L. Wolf, might review with Cannon the methods and data that led to his use of sodium bicarbonate in treatment of shock. At first Cannon had some trepidation about the outcome of such a review, for Wolf, a well-trained biochemist who had a reputation for speaking his mind, told him plainly that he had come as a sceptic. By the end of the conference, however, Wolf along with the others had been won over. "The presence of Wolf and Bayliss all through the week . . . has been a great support", Cannon wrote home some days after the review. "They have seen my method and found nothing at fault, and they have discussed the suggestions which I have made and come to agree with them. And in consequence, though isolated from all access to literature on the subject, I feel quite secure in my stand... The methods which we have tried here have been described and are being tested in neighbouring clearing stations. I suppose that in a month or two we shall know more about their workings." 33

The meeting had an equally positive effect on Bayliss. Soon after his return to London, he wrote Cannon that the MRC had just formed a special committee on shock and extended a formal invitation to him on behalf of the committee to become one of its members. ${ }^{34}$

${ }^{30}$ Cornelia J. Cannon to Cannon, 24 August 1917. It is of interest that Cannon did not raise the question as to whether the beneficial effects of bicarbonate solution might have been the result of the expansion of plasma volume, rather than raising the alkali reserve.

${ }^{31}$ Copy of preliminary report made to Col. Cuthbert Wallace by Dr. W. B. Cannon, 24 July 1917; 4-page typescript in A. N. Richards Papers, University of Pennsylvania Archives.

32 Cannon, 'A consideration of the nature of wound shock', note 7 above, pp. 81-3.

${ }^{33} \mathrm{LH}$, pp. 92-3. Of his relations with Bayliss, Cannon concluded, "Bayliss has been so quiet and modest-no one would take him to be one of the world's foremost physiologists. It has been a great privilege to be associated with him during these days. We have done experiments together, gossiped about physiologists, talked about work ahead, discussed views of shock and had a most delightful and friendly time getting better acquainted."

34 Bayliss to Cannon, 9 August 1917; Walter Fletcher to Cannon, 10 August 1917. The Special Committee on Shock and Allied Conditions of the MRC held its first meeting in London on 17 August 1917, with Ernest Starling in the chair and Henry Dale as secretary. The other members, besides Bayliss and Cannon, were F. A. Bainbridge, T. R. Elliott, John Fraser, A. N. Richards, C. S. Sherrington, and Cuthbert Wallace. 


\section{Walter B. Cannon and the mystery of shock}

Heartened by the outcome of the conference, Cannon began a new series of experiments to find answers to some of the problems that still troubled him-among others, the relationship of acidosis to blood pressure, as well as the effect of anaesthesia on the development of acidosis during operations on patients in shock. With regard to the first problem, he quickly discovered that blood pressure and acidosis were closely and inversely related - that is, the greater the degree of acidosis, the lower the blood pressure. The practicality of finding a solution to the problem of the effect of various anaesthetics on acidosis during operations on patients in shock particularly appealed to him. In fact, the answer seemed almost to be in the inkpot when Geoffrey Marshall, an English surgeon, reported that he had found much less deleterious effects in shock cases if the operation was done under an anaesthetic mixture of nitrous oxide and oxygen, rather than ether or chloroform. (LH, p. 96) By mid-August Cannon, after studying the effect of different anaesthetics used by Fraser in operations on patients in shock, was able to establish that use of ether not only increased the acidosis, but it lowered the blood pressure as well, and that nitrous oxide and oxygen caused little if any increase in acidosis and scarcely influenced blood pressure. ${ }^{35}$

A note to Bayliss about the results of the extension of his investigation of acidosis brought an intriguing response: "It is very puzzling to know what is the real cause of 'shock,' other than that of haemorrhage", Bayliss replied. "One wonders whether the low blood pressure produces the acidosis, or vice versa. And whichever it is that is primary, what is it that brings this about? .. I am somewhat inclined to think, after all, that perhaps afferent stimuli may play a part, but the difficulty in experimental work will be to produce a state of shock similar to the clinical one." ${ }^{36}$ Colonel Wallace remained enthusiastic about the progress of Cannon's investigation and requested Cannon's commanding officer at Camiers to extend his leave even further so that he might conduct needed experiments in London with Bayliss. Cannon, seeking more substantial official support, decided to go to Paris to tell authorities at American Medical Headquarters about the substance of his research and the necessity of his transfer to Bayliss's laboratory to carry the investigation forward. (LH, p. 116)

Cannon's visit to Paris provided all that he had hoped for and more. Colonel Alfred E. Bradley, chief of surgery for the American Army, listened intently and with approval to Cannon's account of his work at Béthune, and then urged him to continue his research in London and prepare suggestions for him on how to deal with shock before American troops became actively involved in combat. For Cannon, Bradley's favourable expression of interest not only stood as authorization for his plan to extend his investigation of shock with Bayliss and others, it also held out the hope that his findings would be applied by the American Army when it went into the line in France. (LH, pp. 120, 122)

A chance meeting with Alexander Lambert, head of the Division of Medical and

\footnotetext{
${ }^{35}$ Cannon, 'Acidosis in cases of shock', note 23 above, pp. 54-7. Marshall's observations were reported in the Proc. R. Soc. Med., Section of Anaesthetics, 1917, 10: 25. Wallace and Fraser later paid tribute to Cannon for his work on the effect of anaesthesia on the development of acidosis during operation on patients in shock in their volume on Surgery at a casualty clearing station, note 17 above, pp. 20-1.

${ }^{36}$ Bayliss to Cannon, 25 August 1917.
} 


\section{Saul Benison, A. Clifford Barger, and Elin L. Wolfe}

Surgical Services of the American Red Cross in France, brought more good news. Lambert, who had known Cannon for some years, informed him that he had taken the liberty of appointing Cannon to an Advisory Committee of the Red Cross. It was an important post since the Red Cross was in charge of medical research for the American Army. When Lambert learned that Cannon needed a number of instruments to conduct his research on shock, he indicated that he had at his disposal any amount of money that Cannon might call upon to extend his work. ${ }^{37}$

On his return to Béthune, Cannon began work on several problems that he felt needed to be answered before he left for London. First, he sought to determine the blood sugar level of patients in shock in the hope that such determinations might reveal whether the inception of acidosis in the wounded was a "starvation acidosis" brought on by a carbohydrate-deficient diet or a lack of food and water before and after action on the battlefield; second, he began to examine the possibility of providing the badly wounded with a reserve of material in the blood that would fortify them against the dangerous drops in blood pressure and the increase in acidosis which accompanied operations; and third, he tried to develop efficient methods to prevent the onset of secondary shock in wounded patients during their transit from aid stations in the trenches to the rear. ${ }^{38}$

The first problem was solved very quickly. After several days of measuring the sugar content of the blood of the badly-wounded men brought into C.C.S. No. 33, Cannon found that his patients had normal blood sugar. As his investigation of the second problem entered its final stage, he took great pleasure in detailing for his wife the practical application of some of his new findings. "As soon as the operation starts," he wrote in one letter, "I have been running a pint of a 4 percent solution of sodium bicarbonate into a vein. The results have been extraordinarily good. The patients survive the ordeal of operation with a higher blood pressure than they had before going under the anaesthetic and their acidosis instead of being increased may be changed back to normal with good margin to spare. Fraser is now so pleased with the clinical results that he insists on this prophylaxis now in all critical cases." (LH, p. 150)

The solutions to the problems that Cannon had set for himself before leaving Béthune were in large measure the result of the splendid cooperation that existed between himself, Fraser, and Cowell. Indeed, Cowell, at Cannon's request, returned to the trenches time and again to develop effective methods to prevent the onset of secondary shock in seriously injured patients during transit to the rear. It was Cowell

\footnotetext{
${ }^{37}$ LH, pp. 120, 124. The committee that Cannon joined was established by the Red Cross Commission to Europe after the War Council had authorized an appropriation of $\$ 100,000$ for medical research in France. However, when some members of the Red Cross objected to the use of contributions for research involving animal experimentation, a private donor (Cleveland $\mathrm{H}$. Dodge of New York) provided a restricted fund to be used solely for investigations that would lead to improved methods of prevention and treatment of diseases and wounds incurred in the war. See further 'History of the American National Red Cross, Vol. IV, The American National Red Cross in World War I, 1917-1918', pp. 367-9; typescript in the American Red Cross Archives, Washington, D.C.

${ }^{38}$ See, e.g., Cannon's sections on the sugar content of the blood and on the effect of anaesthesia and operations on existent acidosis and low blood pressure in 'Acidosis in cases of shock', note 23 above, pp. 53-7; also Cannon, Fraser, and Cowell, 'The preventive treatment of wound shock', in Investigation, note 7 above, pp. 93-104.
} 


\section{Walter B. Cannon and the mystery of shock}

who later emphasized that one of the chief factors in the initiation of secondary shock was the loss of body heat in the wounded. The recommendations that Cannon, Cowell, and Fraser later jointly made, that the wounded be protected from prolonged exposure to cold, provided with warm drinks, and carried to the rear in specially prepared dry stretchers, stemmed from Cowell's patiently-made observations. ${ }^{39}$

These results in hand, Cannon set out for London. There can be little doubt that at this time he was certain that acidosis was a primary cause of shock, and further that an intravenous infusion of sodium bicarbonate provided a therapeutic measure that could help severely wounded soldiers through the operations they needed. Such was Cannon's confidence in the results of his research at Béthune that he assured authorities at U.S. Army Medical Headquarters who wanted him to establish laboratories in France to study the physiological aspects of gas warfare that he would be ready for this new duty following the experimental confirmation of his investigations - which he estimated would be completed in a matter of weeks. ${ }^{40}$

From the outset, London provided Cannon with a welcome change from France. He was particularly pleased soon after his arrival with the opportunities that leisure provided-such as dining at the Royal Society, or exchanging ideas on medical research and education with Lord Haldane, Walter Fletcher, and Joseph Barcroft, or chance meetings with Harvard colleagues and former students. Best of all, he relished discussing with Bayliss and Starling and others the current status of work on shock. For the rest, he began to write up the results of his investigations at Béthune and to study and review the literature on shock that had not been available to him in the field in preparation for his research on acidosis with Bayliss. He looked forward eagerly to participating in the discussions of the MRC Shock Committee. ${ }^{41}$

At the initial meeting of the Shock Committee that Cannon attended, he said little but listened prudently to the views and observations of others-not only reports from Ernest Cowell and Keith Walker at the front, but also accounts by F. A. Bainbridge and E. H. Starling on their efforts to produce shock experimentally, by H. H. Dale and A. N. Richards on their analysis of the shock-like condition produced by histamine, and by Bayliss who favoured the addition of sodium bicarbonate to the infusion of gum acacia he was then developing for widespread distribution as a replacement for blood. At the meeting held the following week, however, Cannon virtually held the floor when he outlined the results of his investigations at the front, reviewed the theories of the nature of shock advanced by George Crile, Yandell Henderson, and W. T. Porter, and reported cases that had benefited from the alkali treatment he was urging. Cannon's presentation provoked considerable debate. While the discussion does not appear to have been heated, enough questions were

\footnotetext{
${ }^{39}$ Ibid., pp. 94-8.

${ }^{40}$ Cannon was initially recommended for the post with the U.S. Gas Service by his friend Walter Boothby, who gleefully boasted of "stealing him" from the British. Cannon's reluctance to leave his work on shock at this time is evident in some of his letters to his family (LH, pp. 106-7, 137-8, 145-7, 150).

${ }^{41} \mathrm{LH}$, pp. 180, 181. The investigations at Bethune were published as the second report of the Special Investigation Committee of the MRC on 25 December 1917. Sir Walter Fletcher and the military censor consented to the subsequent reprinting of the papers in the Journal of the American Medical Association, where they appeared as 'The nature and treatment of wound shock and allied conditions', by W. B. Cannon, E. M. Cowell, John Fraser, and A. N. Hooper (1918, 70: 520-35, 607-21).
} 
raised for the committee to recommend that the different lines of inquiry already underway be investigated further as soon as possible. ${ }^{42}$ For Cannon, such a response meant that his efforts in France were proving not only useful but also stimulating to future work. At the same time, it began to dawn on him that his British colleagues had deep-rooted convictions of their own about both the nature and the treatment of shock.

All, on the one hand, believed that oligaemia - a deficit of the volume of blood in circulation - was a central feature of the circulatory collapse in shock; all, on the other hand, agreed that no theory put forward thus far adequately explained the pathogenesis of the syndrome. Bayliss, like Cannon anxious to improve treatment of shock, had developed an infusion containing a colloid, gum acacia, which could be injected intravenously to replace the plasma that had escaped from the circulation. Although he kept an open mind on acidosis as a cause of shock, at no time during his collaboration with Cannon in the winter of 1917-18 did Bayliss put his research on blood substitutes aside. ${ }^{43}$

Dale also focused on the problem of loss of blood volume, but unlike Bayliss, he was primarily concerned with cause rather than treatment. A brilliant pharmacologist, Dale from the beginning of the MRC's shock programme searched for a chemical trigger that might be responsible for the onset of shock. That search was sparked by an investigation that he and an associate, Patrick Laidlaw, had begun some years before on histamine-a substance they had extracted from intestinal mucosa which had a potent vasodilator-depressant action in animals. The unusual activity of histamine intrigued Dale and he came to believe that it might serve as a model to unravel the mysteries of shock. ${ }^{44}$

Dale, first with Laidlaw and then with the help of Richards, found that histamine caused profound hypotension in cats, dogs, and monkeys by two major activities: first, by vasodilatation of small blood vessels - arterioles, capillaries, and venulesand second, by increasing capillary permeability with resultant loss of plasma into the tissues, thus reducing venous return and cardiac output. In summary, they concluded that "Shock, as produced by histamine, seemed to us, then, to be a condition in which the circulation failed, and the arterial pressure fell to a low level . . . because the blood drained away into the capillary network and tended to stagnate there, instead of returning to the heart through the veins." 45

\footnotetext{
42 MRC Special Committee on Shock and Allied Conditions, minutes of meetings for 2 and 9 November 1917; on file at the Medical Research Council in London. We wish to acknowledge the kindness of Mary Nicholas, Librarian, for the courtesy extended to Dr Barger during his visit there in July 1988.

${ }^{43} \mathrm{Gum}$ acacia was proposed as an inexpensive and readily available expander of plasma volume. See further W. M. Bayliss, Intravenous injections to replace blood, Report No. I of the MRC Special Investigation Committee on Surgical Shock and Allied Conditions, 1917, revised 1919; also Bayliss, Intravenous injection in wound shock, London, Longmans, Green, 1918.

${ }_{44}$ The early work was reported as H. H. Dale and P. P. Laidlaw, 'The physiological action of B-iminazolylethylamine', J. Physiol., 1910-11, 41: 318-44; also Dale and Laidlaw, 'Further observations on the action of $\beta$-iminazolylethylamine', ibid., 1911-12, 43: 182-95. The resumption of Dale and Laidlaw's work on histamine was given a prominent place in the 'Memorandum upon surgical shock and some allied conditions issued by the Medical Research Committee' (published in the British Medical Journal, 24 March 1917, pp. 381-3; see also editorial, 'The nature and prevention of shock', in the same issue, p. 397).

${ }^{45}$ H. H. Dale, P. P. Laidlaw, and A. N. Richards, 'The action of histamine: its bearing on traumatic toxaemia as a factor in shock', in Traumatic toxaemia as a factor in shock, Report No. VIII of the MRC
} 


\section{Walter B. Cannon and the mystery of shock}

Convinced that he was on the right track with his research on histamine, Dale from the outset was sceptical of Cannon's belief that acidosis was the cause of shock. In September of 1917, some weeks before Cannon arrived in London, Dale informed the Shock Committee that experiments he had conducted with Richards indicated that acidosis did not lead to a serious fall of blood pressure, as Cannon had claimed. ${ }^{46} \mathrm{At}$ this time, however, Dale, a consummate politician, did not press an attack against Cannon's theory. Instead, he decided to wait for the results of Cannon's corroborative experiments with Bayliss before speaking out again on the subject of acidosis.

Cannon and Bayliss's experiments began in late December of 1917 and as they continued into the new year, they appeared to confirm Cannon's original observations that as the alkali reserve diminished, blood pressure fell to shock levels. ${ }^{47}$ In one series of experiments in mid-January, after injecting hydrochloric acid of varying concentrations into cats, which were decerebrated to obviate the need for continuing anaesthesia, Cannon recorded in his diary, "Bayliss and I again show acid lowers blood pressure to state of shock." A week later Cannon, in a new experiment in simulation of wounds occurring in combat, tried to produce shock by traumatizing the muscles of an anaesthetized cat. "A great day", he observed following the experiment. "Acidosis developed and as it reached about 38 percent $\mathrm{CO}_{2}$ capacityshock blood pressure."48 Each day that followed brought new confirmation of the effect of traumatizing muscle on the development of acidosis and production of shock. By the end of January, Cannon could no longer contain his excitement and he wrote home, "Confirmation of the crucial experiment on the effects of injured muscles in producing shock and reducing the alkali reserve has continued. I wrote to Surgeon General Wallace about the observations, and was pleased to see in his answer an agreement with my own opinion that we have probably got the key to the mystery of shock. These are exciting days, almost every one of them brings forth something interesting and significant." (LH, p. 259)

Brimming with confidence, Cannon wrote up the results of the experiments he had conducted with Bayliss, thinking to press the Shock Committee to get a report of their work printed and circulated as quickly as possible to all concerned with wound shock and its treatment. Appalled at Cannon's headlong rush, Dale counselled delay. "I found myself in a very difficult position", he later remembered.

Special Investigation Committee on Surgical Shock, 1919, p. 12. See also Dale and Richards, 'The vasodilator action of histamine and of some other substances', J. Physiol., 1918-19, 52: 110-65; Dale and Laidlaw, 'Histamine shock', ibid., pp. 355-90. When Laidlaw was drafted in the summer of 1917 to serve in the pathology department at Guy's Hospital, Dale, anxious to extend the research on histamine, recruited Richards, a young pharmacologist from the University of Pennsylvania, to serve in Laidlaw's place.

${ }^{46}$ MRC Special Committee on Shock and Allied Conditions, minutes of meeting for 27 September 1917; see also LH, p. 138.

${ }^{47}$ Cannon's experiments throughout December may be followed in his 1917-18 diary entries; see especially his note for 22 December 1917. Years later, Cannon recalled the feeling of privilege he had experienced as a worker in Bayliss's laboratory at University College: "It was at a time when the building was almost bereft of investigators because of the demands made by the War. Such work as was being done was definitely in ad hoc researches . . . Never before had I been able to work in a foreign laboratory, and that gratification of an old wish was a part of the pleasure and satisfaction which I had in the autumn and winter of 1917-18." (Cannon to C. Lovatt Evans, 4 May 1934).

48 Diary entries for 14 and 22 January 1918. 


\section{Saul Benison, A. Clifford Barger, and Elin L. Wolfe}

In the evidence, as put before the Committee, I could find no adequate ground for believing that the condition produced by infusing acid into the cats, under urethane, had any necessary relation to the genuine wound shock with its circulatory failure admittedly due to oligaemia; or, on the other hand, for believing that the latter condition was due to acidosis, instead of the acidosis being the result, or the concomitant of the oligaemic shock ... I was deeply concerned, however, to avoid a hasty distribution of a Report, leading to conclusions which, put forward by physiologists of such standing, would be immediately accepted and applied, with results which I should have expected to be, at best, tragically disappointing, to involve us in endless arguments and excuses, and then to produce indefinite delay and difficulty in persuading the army authorities to accept other and more surely based methods for trial. ${ }^{49}$

When the Committee subsequently agreed to postpone any action for several days, Dale, convinced that further argument was useless, decided that only a practical demonstration-results from a precise repetition of Bayliss and Cannon's experiments with acid infusions - would be able to change Cannon's mind. There was no gainsaying the results of these new experiments. "The week has been a strenuous one, and rather exciting", Cannon wrote home soon after.

... Yesterday Bayliss and I went to the Lister Institute and helped in an injection of acid under local anaesthesia, and no shock developed. Then we anaesthetized the animal with ether, and I injured the muscles. In about half an hour the blood pressure began to fall. At this time the alkali reserve had been reduced from what it was before the muscle injury by 33 percent. The pressure went directly down to a shock level, and respiration petered out, just as in our experiments. It looks as if there were two factors at work, the acidosis and something else, possibly a substance given off by the injured tissues, which cooperate, and that under urethane the cooperating substance is provided. $^{50}$

If Cannon appeared to hold onto acidosis as a factor in producing shock, Dale was more definite about his interpretation of the experiments conducted in his laboratory. "By this time", he later recalled, "our friends were ready to 'throw up the sponge' and to agree with the view which we had been urging them to consider, that the low alkali-reserve, which had been observed in men suffering from wound shock, must be a consequential symptom of the circulatory defect, and could not be the cause of it."51

At no time following these experiments on acidosis did Dale claim that histamine was the sole cause of shock. Instead he suggested a more complex origin; namely, that substances with similar activity absorbed from wounds involving injury to tissues, in conjunction with haemorrhage, exposure to cold, and so forth, could well determine the onset of shock. If this were so, he argued, it would be senseless to treat shock with alkali or constricting agents; indeed, the only treatment that could meet the needs of a

${ }^{49}$ H. H. Dale, 'Autobiographical note', p. 158; unpublished memoir in Dale Papers, Royal Society, London. See also MRC Special Committee on Shock and Allied Conditions, minutes of meeting for 19 January 1918; LH, p. 254.

${ }^{50}$ LH, p. 263; MRC Shock Committee, minutes of meeting for 8 February 1918.

${ }^{51}$ Dale, op. cit., note 49 above, pp. 161-2. 


\section{Walter B. Cannon and the mystery of shock}

profound decline in blood volume accompanying shock was a transfusion either of whole blood or of a blood substitute like gum acacia. ${ }^{52}$

Within days of Dale's experiments, Cannon, in response to orders to report to the American Gas Service, left for France. Although he had been preparing to go for some weeks, it was with mixed feelings that he finally departed. "This is the first time that I have had to break away from a deep interest", he wrote just before leaving, "and do something I don't like to do. I appreciate anew the value of university freedom of research." (LH, p. 263)

When Cannon in the fall of 1917 had given his word that he would join the Gas Service after he had completed his experiments on shock, he began to study the rapidly growing literature on gas warfare and to talk with English physiologists who were engaged in research on its problems. It is clear that from the outset Cannon had doubts that his abilities and previous experience would be useful in the work of the Gas Service. Some of his British friends thought otherwise. Lord Haldane, for one, assured him that by means of an unconventional approach he might see new things that others had overlooked - and even urged that it was his duty to go. Talks with Joseph Barcroft, who was deeply involved with research on war gases, had an even more telling effect on Cannon and at one point made him seem almost enthusiastic about his prospects. "The whole subject", he explained to his wife, "bristles with interesting problems. And one aspect of it, the effects of lessened oxygen supply with increase of carbonic acid in the blood, due to inflammation of the lungs, is related with uncanny nicety to the work I have been doing on shock. A good many of the ideas that reading and thinking during the past few months have stirred up are almost directly transferable to the new field of interest." 53

Whatever residual hopes Cannon had of doing useful work in the Gas Service dissipated soon after he arrived in Paris. A request to inspect his new laboratories revealed that the instruments and materials on order for physiological research had not left the United States and were not likely to arrive in France before April. Worse, despite brave talks of research, the Gas Service as yet had no place for him to work. Never one to idle, Cannon determined to take up his investigations on shock and through the kindness of André Mayer at the Collège de France was given laboratory space "only a few hundred yards from the little rooms where Claude Bernard carried on his researches for more than thirty years". (LH, p. 273) By the end of February, however, worn down by a wretched cold and unable to work, he became increasingly depressed about his prospects.

Cannon soon discovered from conversations with various officials in the Gas Service that the major thrust of the physiological work would be to test the new gases devised by chemists and to report on their effects. In his view, such research was at best routine, the kind that anyone could do. Indeed, it appeared to be completely separated from the medical problems presented by human cases. Petty annoyances that he had previously taken in stride became matters of concern that added to his discontent. "For the first time since I entered military service," he complained in one

\footnotetext{
52 H. H. Dale, 'The nature and cause of wound shock', in The Harvey Lectures for 1919-1920, Philadelphia and London, Lippincott, 1920, pp. 38-9.

${ }_{53}^{5}$ LH, p. 245. For Haldane, see also p. 181; for Barcroft, see further pp. 241-5, 248, 250.
} 
letter, "I have been aware of distinctions of rank. Young snips who are Colonels and Majors set me lower than they would one of their own age, for I am old and yet only a Captain ... There is some sort of struggle going on regarding the position of the laboratory in the service and its relation to the Medical Service, but as an underling I have nothing to say about it." 54

Fortuitously, he was rescued from his growing despondency by duties that Alexander Lambert had some time before thrust upon him on behalf of the American Red Cross Research Society. As chairman of its advisory committee, Cannon became the presiding officer at monthly scientific meetings and conferences. It was a post that allowed him to take part in the discussions on all ongoing surgical, physiological, and bacteriological research conducted by the allied armies. ${ }^{55}$

The meetings he attended in Paris in March 1918 gave him the first opportunity since leaving England to speak publicly about the research he had conducted at Béthune and London on shock. Although he candidly reported that Dale and Richards had not been able to corroborate the results of the experiments that he and Bayliss had conducted, he gave little indication that he was willing to completely discard his theory of acidosis as a cause of shock. Instead, he offered an emendation based on the results of his more recent experiments on traumatizing the muscles of anaesthetized cats; namely that in addition to acidosis there were toxic substances released from injured muscles that could lead to shock. ${ }^{56}$

Just as he was preparing for the March meetings of the Red Cross Research Society, Cannon received news that presaged a turn in his fortunes. First, the War Department informed him that he had finally been promoted to Major-a rank that he had for some time felt was more commensurate with his duties and responsibilities. Second, and even of more consequence, J. M. T. Finney of the Surgical Service asked if he would direct a centre for surgical research then being planned in association with the Central Medical Department Laboratory of the A.E.F. at Dijon. Cannon immediately accepted. (LH, pp. 283-4, 286) The new post offered him an opportunity not only to continue his experimental research on shock but also to transmit first-hand to American medical personnel the lessons he had learned at Béthune in caring for shocked cases at the front. The only problem that remained to be solved was his transfer from the Gas Service to the Surgical Service, a matter that Finney arranged with little difficulty.

Cannon's call to Dijon was indeed a great stroke of luck. For the first time since he returned to France, he did not have to persuade his superiors of the importance of the research he wished to do. Colonel Merritte W. Ireland, the chief medical adviser to

\footnotetext{
54 Cannon to Cornelia J. Cannon, 6 March 1918. This is one of several instances where sections of Cannon's letters were deleted from the typed transcript. See also LH, pp. 278-9.

55 For more on Cannon's appointment, see LH, esp. pp. 184, 255, 270. The formation of the Red Cross Research Committee and Society was announced in the first number of their Medical Bulletin, published in Paris, November 1917. With its eighth number, issued in June-July 1918, the title was changed to War Medicine, Surgery \& Hygiene. For a historical review of the Medical Research Committee of the American Red Cross in France, see further War Med., 1918-19, 2: 1588-97.

${ }_{56}$ Reports of the monthly Red Cross Research Society meetings were published regularly in the Medical Bulletin and its successor War Medicine. The session devoted to the subject of traumatic shock, chaired by Gen. Cuthbert Wallace, was held on 15 March 1918, and reported in the April issue. Cannon's remarks appear on pp. 424-8.
} 


\section{Walter B. Cannon and the mystery of shock}

General Pershing and soon-to-be chief surgeon of the A.E.F., needed no instruction as to the importance of experimental research. A regular army medical officer, he had previously played an important role in organizing the yellow fever and trench fever experimental teams. Colonel J. F. Siler, who was to be the military commander of the Dijon laboratories, from his own investigation of hookworm, pellagra, and dengue fever knew well the importance of meeting the needs of those engaged in investigation. "The laboratories can have anything that is desired", Cannon elatedly wrote home, "-men detailed from any unit, materials at whatever cost, and transportation of the most effective sort." (LH, p. 290)

Equally important, Cannon found some of the personnel who were already at the Dijon laboratories to be kindred souls to whom he immediately became attached, including among others, Hans Zinsser, a distinguished microbiologist from Columbia University; Paul De Kruif, a young immunologist who had trained with Frederick Novy at Michigan; and Jack L. Yates, a thoracic surgeon from Milwaukee, who had previously collaborated with him in his struggles against the anti-vivisectionists in Wisconsin. Beyond their common research interests, Cannon found most stimulating the variety of opinions that the group had on social and political issues. "Last evening after dinner," he reported in a letter home, "we sat around the table and had a long and very lively discussion about democracy, the dangers of labor control, compulsory military service, and the probable effects of the war on the United States ... We all disagreed heartily. It was almost the best conversation I've heard since coming to Europe, and I was delighted with the prospect of such company. Since the new outlook opened, my whole feeling has changed. I can push ahead now with interest, enthusiasm, and confidence." 57

Foremost in Cannon's mind, as he undertook the opening of the Dijon laboratories, was the conviction that the research conducted there could fruitfully be applied to the solution of a wide variety of medical problems facing American troops in the field. Each and every achievement of medical research that came to his attention became proof of the superiority of American methods; even more, he fully believed that such achievements could become the foundation stones for an important collaboration with England and France in future. "All these countries", he noted, "need to know each other better, and one of the best means is through uncontroversial ways of science and love of learning. I am just beginning to appreciate what France has to offer us in the forms of suggestion and insight, and what we may have to offer her in new enterprises." 58

Cannon approached his own research at Dijon with some ambivalence. Despite Dale's telling criticism, he was still unable to make up his mind about acidosis as the cause of shock. But when Bayliss wrote him that he had been unable to confirm their earlier experimental results on acidosis, Cannon began a cautious retreat. "It

\footnotetext{
${ }^{57}$ LH, pp. 287-8. Before long, a friendship had sprung up between Zinsser, Cannon, and Yates that developed into a deep and lasting bond.

${ }^{58} \mathrm{LH}$, p. 321. While at Dijon, Cannon served as president of a local group made up of American and French medical officers stationed there. Ever since his return to France, he had begun to study French seriously and, when time allowed, to read French history and literature and attend meetings of the Cercle Artistique et Littéraire, to which he had been elected.
} 


\section{Saul Benison, A. Clifford Barger, and Elin L. Wolfe}

certainly looks as if acidosis plays a secondary role, if any", he confessed to Bayliss, but then in the very next breath added equivocally, "I am inclined to continue to give sodium bicarbonate by mouth to injured men and to reserve intravenous injection of it to the seriously wounded who have to be operated upon before their blood pressure has been restored." 59

Following the receipt of Bayliss's letter, Cannon put his research on the cause of shock aside and began instead a series of investigations designed to extend some of the ideas for treating shock that had emerged from his experience at Béthune. These included, among others, a study of the best methods of applying heat to the wounded to prevent the onset of secondary shock and an analysis of the utility of gum acacia in restoring blood volume in the seriously wounded, as well as an examination of the effect of light versus deep anaesthesia on blood pressure in a shock state. While each of the problems was intrinsically important in dealing with shock, Cannon well understood that the ultimate success of his research would lay in maintaining good relations between the laboratory and surgeons at the front. To further those relations, he decided to establish a network of resuscitation teams to undertake the care of shocked soldiers on or near the battlefield. (LH, pp. 326-7)

The project was a daunting one. There were no existing models that Cannon could rely on as a guide, since neither the British nor the French had such units. The physicians and surgeons that Cannon wished to train presented other difficulties; some were poorly educated, others had no experience with sphygmomanometers or knew little of blood transfusions. Cannon took such problems as they came and, with characteristic energy and enthusiasm, organized a one-week training course that contained lectures on subjects ranging from the physiology of circulation and haemorrhage, and anaesthesia and shock, to the principles involved in blood transfusions. These lectures he buttressed with a set of laboratory demonstrations designed to illustrate the various elements in the experimental production of shock, as well as those involved in the care of patients in shock. ${ }^{60}$

From their inception, the programmes instituted by Cannon gave the laboratories at Dijon the aura of a busy beehive-and they soon attracted a steady stream of important visitors. The ensuing kudos pleased Cannon but his pleasure was tempered by dismay. "The only trouble we are finding thus far", he commented wryly in a letter home, "is that everybody wants to show us off, and in consequence there are frequent interruptions." (LH, p. 337) The visits, despite his complaints, did not perceptibily affect the progress of the research he had begun in collaboration with his former student McKeen Cattell on the relation of anaesthesia to the development of shock,

\footnotetext{
${ }^{59}$ Cannon to Bayliss, 24 April 1918, in response to letters from Bayliss of 16 March and 3 April 1918. In the first of his letters Bayliss had written to Cannon, "You always speak so kindly of the time you spent with us that I feel hesitation in criticizing what you say, but one cannot help the experiments going as they do." For a detailed discussion by Bayliss on acidosis, see his Intravenous injection in wound shock, note 43 above, p. 60.

${ }^{60}$ Mimeographed syllabus, 'Course of instruction for preliminary training in resuscitation work for the wounded'. For a more detailed description of the resuscitation training programme, see Cannon's typescript report, 'Historical record of the services of the laboratory of surgical research, American Army, at Dijon, 1918' (esp. pp. 2-12), which was sent with letter of enclosure to General J. M. T. Finney on 2 December 1918.
} 


\section{Walter B. Cannon and the mystery of shock}

although some of their results tended to substantiate Dale's and Bayliss's rejection of acidosis as a cause of shock. "The increase in acidosis accompanying anaesthesia which I noted last summer in Béthune", he admitted to Bayliss in one letter, "is apparently the consequence of the fall of blood pressure and not the occasion for it. You can see that these observations give quite another turn to my thinking and are pertinent to the work which we were doing last winter.",61

In a letter to Dale several days later, he continued in the same vein. "The experiments we have done here have modified considerably my general attitude. Perhaps the most important among them as affecting my thinking is the fact that we do not observe a reduction of the alkaline reserve in consequence of operative procedure ... The sharp drop in pressure and increase of acidosis which I observed last summer may be accounted for by sensitiveness of the control of the circulation in the shocked animal to ether anaesthesia. I recall that you and Richards made a few observations on this point last fall. You can see that somewhat tardily I am drifting towards your view of the relation between anaesthesia and the action of acids." 62

Dale was happy with Cannon's letter. It appeared to him that Cannon's changing attitude towards acidosis promised that he could write a memorandum on the problem of acidosis and shock that would be acceptable to all members of the MRC's Shock Committee. "I confess to some feeling of relief", he responded to Cannon's letter, "that there is more prospect of our views on the relationship of the acidosis approximating ... As it happens, the results of your investigations, now that you have time to go steadily ahead, are bringing you much nearer to the position as we stated it last Autumn; namely, that low blood pressure produced in any way will lower the alkali reserve, while lowering the alkali reserve does not, per se, produce low blood pressure. Bayliss has for some time past been in agreement with this and it is cheering to know that you have moved so far in the same direction."63

As the resuscitation programme progressed, Cannon applied for permission to travel freely to forward areas to inspect the performance of his trainees under the conditions of battle. Although Finney and Siler enthusiastically endorsed his inspection trips, Cannon, to his consternation, found himself increasingly thwarted by a jealousy that had begun to manifest itself between regular army men and "civilians" like himself. "We had planned to go up to the evacuation hospitals and the aid posts in the front line on Monday", he confided to his wife, "in order to see the conditions under which the resuscitation teams would have to work, but the conflict of authority had reached an acute crisis, and it was deemed inadvisable for us to go just at the moment." For the time being, Cannon had to comfort himself with the hope that ultimately what was best for the wounded soldiers would prevail. (LH, p. 332)

${ }^{61}$ Cannon to Bayliss, 21 May 1918. Cannon's research with Cattell did not reach publication but is described in the 'Historical record', note 60 above, pp. 14-15. Cattell's previous work with Cannon at Harvard on the thyroid was reported in a series of three articles in the American Journal of Physiology in 1916; see further Benison, Barger, and Wolfe, op. cit., note 2 above, pp. 326-9.

62 Cannon to Dale, 25 May 1918.

${ }^{63}$ Dale to Cannon, 3 June 1918. When Cannon was in London later that month to give the Croonian Lecture at the Royal Society, he attended a meeting of the MRC Shock Committee, at which Bayliss, Bainbridge, Laidlaw, and Dale were present (20 June). "I reported on the recent work", he wrote home, "and the new interpretation it suggested for last summer's experiences, especially the acidosis and effects of 


\section{Saul Benison, A. Clifford Barger, and Elin L. Wolfe}

The differences, however, continued to simmer. As Cannon's frustration grew, Siler, in an effort to breach the barriers placed in his way, assigned him to temporary duty with the medical unit of the 42nd Rainbow Division facing German troops in the region of Chalons-sur-Marne. Within days of his arrival early in July, Cannon found himself in the midst of a fierce battle. Although he had been under aerial bombardment and shellfire at Béthune, that experience did not match the savage day-long bombardments of this German drive. From the beginning of the battle he worked continuously with the shock teams as the front-line hospital alternately reeled under both the intense shellfire and the flood of wounded men. When the bombardments temporarily halted, the hospital was ordered to move its wounded and equipment to Écury, thirteen miles from the front lines. It hardly proved a respite.

"No sooner did I arrive [at Écury]", Cannon wrote home, "than I was directed to the shock ward. It was... already filled with sickening sights associated in my memory with Bethune. Men with their bellies torn open, with the sides of their faces ripped out, with brains oozing from skull wounds, with the bladder shot through, with sucking chest wounds - these were the hopeless, pathetic cases left in the shock ward." By the second day those who had not already died were "likely to be weakened and septic, or restless with approaching death. Cursings, expletives, repeated shouts for 'mother', or for 'mama' or 'papa', and the stench of septic wounds and dressings, make the shock ward a desperate and depressing place. As soon as a man has picked up and is out of danger, he is removed to another ward where conditions of surgical care and attention are more favorable and where there is relative quiet. Of course such selection leaves the [shock] ward always a center for the very bad and hopeless cases." 64

The horrors of the battle remained fixed in Cannon's mind for the rest of his life. More immediately the experience enlarged his understanding of the difficulties involved in improving the resuscitation of the wounded in shock. All in all, he was pleased by the performance of the resuscitation officers he had trained. Nevertheless, he found their effectiveness was vitiated by the quality of the care the wounded had received at front-line aid stations-in part, by triage officers who had difficulty separating moribund shock patients from those who might yet benefit from evacuation and treatment, but more especially by surgeons who still did not understand that it was necessary to keep the wounded correctly blanketed and given warm fluids and judicious rest in order to prevent the onset of secondary shock. Other observations persuaded Cannon that base hospitals needed more than one resuscitation team to care for shock cases during battle and that it would be useful to establish clinical pathology laboratories at the front lines to send back data for the

\footnotetext{
anaesthesia. We decided at the end to try to get out a joint memorandum on the whole subject of the relation between acidosis and shock." (LH, p. 373)

${ }^{64}$ LH, pp. 400-2; see also Cannon, The way of an investigator, New York, W. W. Norton, 1945, pp. 138-40. Cannon's service in this engagement, referred to as the Battle of Champagne, as well as his service in the Battle of St Mihiel of September 1918, was later recorded on his military discharge, along with his awards of the Cross of the Companion of the Bath from the British government and the Distinguished Service Medal from the U.S. War Department.
} 


\section{Walter B. Cannon and the mystery of shock}

subsequent treatment of patients at the rear. In sum, he was convinced that the laboratories at Dijon should be allowed to expand the resuscitation programme. ${ }^{65}$

The period that Cannon spent with the 42nd Division was not without cost. On his return to Dijon, he discovered to his annoyance that the resuscitation teams had not been adequately trained during his absence. It became clear that he could no longer carry on his various responsibilities without help; he needed a second-in-commandsomeone of comparable status who could not only take over the instruction of resuscitation teams when he was away but also work independently in devising new therapeutic methods in dealing with shock. (LH, pp. 407, 410)

There was no doubt in Cannon's mind as to the man he wanted to join him. For some time he had been impressed, as had others, by the work of $\mathrm{O}$. H. Robertson on preservation of blood for use in transfusions on the battlefield and in military hospitals. Robertson's investigations, which arose from his studies with Peyton Rous at the Rockefeller Institute, led to the development of techniques for preserving red blood cells; he also emphasized the importance of making up the loss of plasma volume by administering fluids by mouth or rectum in cases of haemorrhage. Although Robertson, who had also come over to France as a member of the Harvard Base Hospital No. 5, expressed pleasure at the prospect of working with Cannon, he nevertheless stated that he preferred to continue his studies on blood volume with Arlie Bock at Boulogne, where he was attached to the British Medical Service. Robertson's pioneer work in setting up what was to become the world's first blood bank had such practical application for treating the wounded and saving lives that he was highly valued by the British. "Do please leave him with us if he can possibly be spared", T. R. Elliott pleaded in a letter to Cannon when he heard of the plan to call Robertson to Dijon. "If he goes, I am bereft and desolate."

Cannon, however, was not to be put off. Late in August, with Colonel Siler's help, he succeeded in arranging Robertson's transfer to the laboratory of surgical research. When Robertson finally reported to Dijon, he was to prove of extraordinary value in untangling a problem that increasingly bedevilled surgeons in the field and at base hospitals-the efficacy of using gum acacia in the treatment of shock.

Even before his stay in Bayliss's laboratory, Cannon had been convinced of the utility of gum acacia in restoring blood volume in shock. Later, in his lectures to resuscitation trainees at Dijon, he particularly made a point of stressing its use at the earliest appearance of shock. Although he had seen excellent results from the use of gum acacia during the battle of Chalons-sur-Marne, he nevertheless was taken aback by several cases with unfavourable symptoms, such as marked shivering and cyanosis, following its use. Even though these symptoms were temporary, Cannon promptly

\footnotetext{
${ }^{65}$ See further Cannon's recommendations for improving work in resuscitation in his 'Historical record', note 60 above, pp. 12-14.

66 T. R. Elliott to Cannon, 22 August 1918; in the archives of the Medical Research Council, London. For Cannon's interest in Robertson, see also LH, pp. 268, 377-8; exchange of letters between Cannon and Robertson, 25 and 31 July 1918; Roger I. Lee to Cannon, 31 July 1918. A brief account of Robertson's work on blood preservation and transfusion may be found in Corner's History of the Rockefeller Institute, note 15 above, pp. 142-4. Robertson's Memorandum on blood transfusion was published as Report No. IV in the series issued by the Special Investigation Committee on Surgical Shock and Allied Conditions of the MRC, 4 April 1918, revised 6 September 1918. The Memorandum on blood volume after haemorrhage (with Arlie V. Bock) was published as Report No. VI in the same series on 8 August 1918.
} 
reported his observations to Bayliss. Bayliss, who had on occasion seen similar symptoms in some of his experimental animals, made little of the phenomenon. Instead, he alerted Cannon to a new development of mutual interest. "I saw McNee yesterday", he wrote. "He has been in charge of a resuscitation ward and made some interesting observations, which I have asked him to send a report of to the Shock Committee. One thing is that he is convinced of the very serious result of absorption of toxic products from injured muscle. He finds that removal of the injured tissue or even application of a tourniquet is followed by marked benefit." 67

Upon receipt of Bayliss's news, Cannon set aside his earlier determination to devote his investigations at Dijon to problems of resuscitation. "During the past three days," he wrote home early in August, "I have taken up again the experiments that Bayliss and I were doing last winter on the relation of muscle injury to shock. There is no doubt that by injuring muscle, shock can be produced. I am trying to analyze the conditions somewhat; Bayliss and I will publish a paper together on the phenomenon." (LH, p. 428) Each day the investigation brought both new and interesting results. Little more than a week later, Cannon reported on his continuing experiments to Army headquarters. "It appears that (a) [muscle] injury does not cause shock through nervous influences and that (b) as long as blood from the injured region is not received by the rest of the body, shock does not occur." In effect, he suggested that a circulating toxic substance released by injury to the muscle might well be the cause of shock. The results of Bayliss's independent experiments pointed in the same direction. "I quite agree", he wrote to Cannon toward the end of August, "that the results must be due to the chemical product of something like autolysis." 68

To follow up his assumption that the fall of blood pressure with tissue injury might be due to early products of protein cleavage, Cannon asked Captain Joseph Aub, one of his former students who had been studying metabolism and venous pressure in shock and haemorrhage, to join him in an experiment with peptone and protease injections to determine if such injections could modify shock. ${ }^{69}$

Throughout September 1918, Dale apprised Cannon of his progress in preparing the memorandum on behalf of the MRC Shock Committee that laid to rest any claims for the theory that acidosis was the cause of shock. Cannon accepted the memorandum with minor emendations, adding at one point an explanation of his support for the use of sodium bicarbonate injections:

I saw magical effects from these injections in cases which had reached the stage of air hunger. And I saw also that operation sharply lowered the alkali reserve, so that at the end men were sometimes gasping for breath. It was for the sake of saving them

${ }^{67}$ Bayliss to Cannon, 27 July 1918, in response to Cannon's letter of 23 July 1918. See further J. W. McNee, A. F. Sladden, and J. E. McCartney, 'Observations on wound shock, especially with regard to damage of muscle', in Traumatic toxaemia as a factor in shock, note 45 above, pp. 33-6.

${ }^{68}$ Bayliss to Cannon, 24 August 1918. Cannon's report to the Commanding Officer of the Central Medical Department Laboratory was for the week ending 16 August 1918.

${ }^{6}$ Cannon, 'Historical record', note 60 above, pp. 15-17. In his report Cannon comments on the difficulties involved in obtaining the necessary apparatus for Aub's metabolic investigations, as well as the wind-down of hostilities in the fall of 1918 , which allowed for study of only a few cases. Aub later took up this work under experimental conditions in the Physiological Laboratory at Harvard and published his results as 'Studies in experimental traumatic shock. I. The basal metabolism', Am. J. Physiol., 1920, 54: 388-407. 


\section{Walter B. Cannon and the mystery of shock}

from these conditions that I proposed giving a prophylactic injection of $\mathrm{NaHCO}_{3}$. I believe now that the same benefits are obtained better by injecting blood or gum-salt solution at the beginning of operation, to hold up the blood pressure. ${ }^{70}$

In conclusion, Cannon appended a note of thanks to Dale for saving him from error. Dale, who later characterized the note as "generous and warm-hearted", responded with equal grace:

It was quite evident that we who had time to go calmly into the matter in England had an advantage over you who were obliged to form your ideas on observations made in the stress of work at a C.C.S., supplemented by a few weeks of high-pressure experiments in England. The great cause of satisfaction to me is not that you came to agree in the end with our first-formed opinion, but that we are at last all on the same track. $^{71}$

There were, however, other problems close to Dale's and Cannon's interests that remained to be resolved-more especially the questions of the relation of muscle injury to shock and of the therapeutic efficacy of gum acacia. When Charles Richet late in August invited him to speak on shock at the Sociéte de Biologie in the autumn, Cannon, intrigued with the findings of some of his experiments on muscle injury, immediately accepted. It was his hope that a forum with the French might provide additional insight and information to support his growing conviction that toxaemia following muscle injury was a cause of shock. Although some of the new experiments he conducted in early September gave equivocal results, Cannon was nevertheless heartened by a closer relationship with Dale, who sent him news of his more recent experiments with histamine-induced shock. "I think we shall all in the end come to believe", Dale wrote him early in October, "that there is more in the effect of retarded circulation than the mere deficiency of oxygen supply. Your further experiments on muscle injury greatly interested the Committee ... I think we shall end by establishing the absorption of toxic products from ill-nourished tissues as at least one factor of importance in shock." A short time later Dale continued in the same vein: "Will you as soon as you can spare the time put together an account of your more recent experiments on muscle injury? We have enough material in sight for what I believe will be a valuable symposium on the relation to shock of absorption of autolytic products from injured muscles."72

The meeting with the Société de Biologie pleased Cannon, especially the strong support that the idea of toxaemia received from many of those present. Eduard Quénu, a distinguished surgical pathologist, maintained that shock was principally

\footnotetext{
${ }^{70}$ Cannon to Dale, 2 October 1918. See also Dale to Cannon, 3, 13, and 20 September 1918. The memorandum was published as Acidosis and shock, Report No. VII of the MRC Special Investigation Committee on Surgical Shock and Allied Conditions, October 1918.

${ }^{71}$ Dale to Cannon, 4 October 1918. Perhaps Cannon's feelings, as he endorsed the formal acknowledgement that his earlier claims for acidosis had been mistaken, may best be gauged by an adage, attributed to T. H. Huxley, that he was later fond of quoting, "The tragedy of scientific inquiry is the slaying of a beautiful hypothesis by an ugly fact." (The way of an investigator, note 64 above, p. 34.)

12 Dale's letters to Cannon were dated 4 and 11 October 1918. For the invitation from Charles Richet, see LH, p. 430.
} 


\section{Saul Benison, A. Clifford Barger, and Elin L. Wolfe}

the result of contused wounds of large muscle tissues, which set toxic substances free that permeated the circulation. He pointed out that in his experience, shock disappeared after he excised the injured muscles. Others present also accepted Quénu's view, especially that shock could be prevented by amputation or removal of the injured tissues. "Do not wait for shock to pass," one surgeon exhorted, "operate to suppress shock." Not all, however, were convinced. A number of surgeons just as resolutely argued that shock was a nervous phenomenon-the result of reflex inhibition - a notion that went back to Weir Mitchell's observations in the American Civil War. Neither Cannon nor Dale, who received an abstract of the discussion, thought the latter position had much merit and largely disregarded it. It is of some interest that almost twenty years later, Cannon would admit in the Annals of Surgery that pain, persistent fear, and great emotional excitement might also play a role in the induction of shock. ${ }^{73}$

Throughout September and October 1918, surgeons in the field increasingly complained of the lack of effectiveness of gum acacia in treating shock. Some, comparing the utility of blood transfusion and gum acacia in therapy of shock, asserted that blood transfusion was by far of greater value. Others claimed that the use of gum acacia was followed by a variety of ill effects including vomiting, chills, and urticaria. Still others announced that it was responsible for a number of deaths. ${ }^{74}$ Bayliss, chagrined by the complaints, sought an explanation in renewed experimentation but to no avail. "The only explanation that occurs to me", he wrote to Cannon, "is either that the solutions which gave chills were made with stale distilled water or that some accidental contamination occurred." For the rest, he concluded that the answer to the problem could well lie in the quality of the gum used. ${ }^{75}$ Cannon, under pressure from headquarters to get more definitive answers to the mounting tide of criticism, put Paul De Kruif to work on problems of toxicity of gum acacia and dispatched Oswald Robertson to forward hospitals to obtain more reliable data about the consequences of using gum acacia. ${ }^{76}$

De Kruif, a well-trained bacteriologist, after a study of the effect of various samples of gum acacia on guinea pigs, reported that properly prepared gum acacia had no demonstrable toxic effects and was relatively innocuous. However, Robertson, after a week of visiting a variety of evacuation, mobile, and field hospitals, informed Cannon that the reported results of the use of gum acacia depended not only on the nature of

\footnotetext{
${ }^{73}$ W. B. Cannon, 'A consideration of possible toxic and nervous factors in the production of traumatic shock', Ann. Surg., 1934, 100: 704-13; see especially p. 708. An outline of Cannon's talk to the Sociéte de Biologie was published as 'Traumatic shock' in War Med., 1918-19, 2: 1367-70; and an abstract of the discussion that followed, translated and reviewed by Dale, appeared in Medical Supplement, 1 December 1918, pp. 437-8.

${ }^{74}$ When reports of the deleterious effects of using gum salt infusions begar to come in from U.S. mobile and evacuation hospitals, General Finney sought to collect data for a general summary; see J. M. T. Finney to Cannon, 23 October 1918. Some of the unfavourable opinions, as reported by C. G. Mixter, R. I. Lee, and others, were later published in War Med., 1918-19, 2: 1276-7; a compilation of responses to Finney's questionnaire appears on pp. 1297-8.

${ }_{75}$ Bayliss to Cannon, 1 October 1918.

${ }^{76} \mathrm{LH}$, pp. 475-6. De Kruif, then a captain in the Sanitary Corps, later published his results as 'Experimental research on the effects of intravenous injection of gum-salt solutions', Ann. Surg., 1919, 69: 297-311. Cannon is mentioned on p. 310.
} 


\section{Walter B. Cannon and the mystery of shock}

the case treated but also on the manner in which gum acacia was given. Some reports from officers in the field, he pointed out, were especially favourable, as when gum acacia was used early in cases of shock with moderate haemorrhage. The causes of failure, however, were far more complex. Robertson noted that some casesespecially those that were in a state of shock with low blood pressure for long periods of time during evacuation-were invariably beyond the help of either blood transfusion or gum acacia. Nor were these cases alone. He also found that patients in shock who were concomitantly infected with gas bacillus did not respond to treatment. At other times failure appeared to be the result of carelessness-either the giving of gum too rapidly or not giving it sufficiently warmed-but he conceded that it was difficult to trace any causal relation between the giving of gum salt injection and the death of a patient. ${ }^{77}$

Perhaps the nub of Robertson's report was that most judgements about the use of gum acacia were impressionistic at best and not based on actual data as to blood pressure changes, haemoglobin concentration, etc. "This is due", he concluded, "partly to the lack of apparatus for these determinations (blood pressure apparatus is especially needed) and partly to the fact that methods commonly used for determining the degree of shock and haemorrhage do not give sufficient information as to the fundamental state of the circulation. It is most important to know the amount of blood loss and the total haemoglobin left in the body." It is worthy of note that Robertson believed that in dealing with shock on a day-to-day basis it was important to concentrate one's efforts on prevention, and he advised Cannon to focus on training divisional medical officers whose business it would be "to carry the instruction in shock treatment to the front line, and to see that the necessary measures are carried out". ${ }^{78}$

Robertson's advice reinforced what Cannon had long been preaching to headquarters. "Ever since early in July", he wrote his wife several days later,

I have been urging by letters, by telephone messages and by complaints, to Colonel Siler, General Thayer and General Finney, the sending here for instruction in resuscitation medical officers from divisions ... In spite of all my efforts I had had here until last week representatives from only nine divisions. I made ructions again after Robertson returned and reported occurrences that made one weep ... and at last on Sunday twenty-five divisional doctors appeared and yesterday twenty-six more. (LH, p. 482)

Although rumours were rampant throughout late October that the war could end in a matter of weeks or even days, Cannon continued his instruction of resuscitation officers much as he had before. "It has been hard work", he wrote home, "but mitigated by the thought that, if the war continues, good will come of it." (LH, p. 483) When Simon Flexner of the Rockefeller Institute and Alexander Lambert of the American Red Cross during a visit to Dijon in early November suggested that

\footnotetext{
${ }^{77}$ O. H. Robertson to W. B. Cannon, 'Summary of observations and certain recommendations concerning the use of gum-salt solution and the treatment of shock', memorandum dated 27 October 1918. See also Robertson's remarks in the discussion of gum-salt solution published in War Med., 1918-19, 2: 1277.

${ }^{78}$ Ibid., A. Gum-salt solution, p. 2; B. Shock work, p. 3.
} 
Cannon join them on a tour of hospitals at the front, it appeared to him that the war was almost at an end. (LH, p. 484) During the next several days they visited the cities and villages of the war-torn front. Although they heard the booming of guns in the distance, at some of the hospitals they visited they discovered that no new cases had come in for days, and at others it seemed as though all of the personnel were off duty. Almost inadvertently, as they passed through a small French village on 11 November, they learned that the war had ended. "The war, the Great War, was over! The incredible had happened", Cannon wrote home. "The first shock brought relief, rather than shouting, and then a sense of wonderment as to how events might move." (LH, p. 488)

Although the fighting stopped and there were no longer any wounded, the problem of shock remained to harass and puzzle military surgeons as well as medical scientists. The former realized that shock was a ubiquitous condition of warfare and apt to reappear in future; to the latter, it presented singular physiological and therapeutic problems that demanded solution. Four days after the armistice, the British Army in France organized a conference at Boulogne for medical personnel to discuss the relative merits of blood transfusion and gum acacia in treatment of shock and haemorrhage. Most of those who attended, such as generals in the field like Cuthbert Wallace and Sir Anthony Bowlby, or medical consultants like T. R. Elliott, or surgeons serving at various casualty clearing stations like J. W. McNee, Ernest Cowell, and Geoffrey Marshall, knew either through personal contact or by reputation Bayliss, Dale, and Cannon, who came as representatives of the British and American scientific establishment. ${ }^{79}$

The criticisms of gum acacia that were made at the Boulogne conference were for the most part either subdued or tentative. Few of those whose opinions were reported by General Bowlby allowed that in their experience there were any "bad effects" of using gum. Typically, George Gask, a distinguished surgeon and consultant to the British Fourth Army, commented that he had never seen any ill effects from the supply of gum acacia that was provided by the Boulogne Medical Laboratories, but he said nothing of the effect of other gums that might have been used. Colonel Edgar Pilcher, a surgical consultant to the British Third Army, had voiced similar sentiments, but then added that he was not in favour of using gum. Casualty clearing station officers who were present at the meeting were equally equivocal. Although some admitted they had seen "chills and rigors" after using gum, they passed them off as "temporary distress". Major J. W. McNee, despite witnessing several deaths after an infusion of gum, quickly added that he was convinced that gum was not the cause of death. T. R. Elliott, who earlier in October had written Walter Fletcher at MRC headquarters in London, "Don't lay too much stress on gum. It is never as good as blood", said nothing at Boulogne. ${ }^{80}$ Bayliss and Dale, too, held their tongues,

\footnotetext{
79 'Conference at Boulogne of surgeons and pathologists of the B.E.F. on treatment of shock and haemorrhage, held on November 15th 1918'; 6-page typescript in the A. N. Richards Papers, University of Pennsylvania Archives. The comments recorded here are taken from this report.

${ }^{80}$ T. R. Elliott to W. M. Fletcher, 19 October 1918; on file at the Medical Research Council in London. Compare McNee's comment here with his later statement: "The infusion of gum solution does not, to a superficial observer, yield nearly the same immediate dramatic effects as are often obtained by blood transfusion. With blood, the man loses his ashen colour, the face and lips redden, and the man's general
} 


\section{Walter B. Cannon and the mystery of shock}

contenting themselves in the main with keeping a record of both complaint and approval for future consideration by the MRC Shock Committee.

Cannon took a more active role in the conference. Using Robertson's report as a guide, he not only delineated the wide range of favourable and unfavourable opinions that American surgeons held of the utility of gum acacia, he catalogued the various factors and situations that contributed to its success or failure as well. The criticism implicit in Cannon's presentation was not about defects in the gum or its purpose, but rather of the lack of judgement on the part of surgeons as to how and when to use it effectively, and worse, their manifest disregard of the elementary measures that could be taken to prevent the onset of shock during evacuation of the wounded from the front lines to the rear.

The opinions voiced on the relative value of the use of gum as compared with blood transfusion were equally controversial. Some at the conference were convinced that when the patient was in obvious shock, blood "ought to be given". Others favoured blood transfusion over gum infusion in most circumstances. Still others were in a quandary of how much blood to give. At no time did Bayliss voice an opinion about the use of blood as compared with gum. In the Oliver-Sharpey Lectures he had given in May 1918, he pointed out that blood was the most appropriate fluid to replace blood. ${ }^{81}$ Several months later, after reading a preliminary report of Oswald Robertson's research on blood transfusion, Bayliss wrote Cannon of the impact of Robertson's achievement on his own work on gum acacia: "I may say, incidentally, that I think it would be a pity if there were supposed to be any kind of conflict between the transfusion of blood and the injection of gum. It seems only natural that blood should be used when available and the value of gum seems to me to be rather in the fact that its use is simpler in times of stress and there need be no hesitation in using it, even in apparently hopeless cases, on the grounds of economy . . It appears that the chief thing is to make up the volume of blood, no matter how, so long as it is permanent." 82

At the end of the conference, it was reported that "no definite conclusion was reached as to the indications for choice between gum solution and blood in resuscitation work". ${ }^{83}$ Actually, it appears from the minutes that little time was spent on the subject of blood transfusion itself. Nothing was said about the giving of transfusions, and especially about problems one would have expected to be discussed: such as obtaining donors, matching blood, preserving red cells, the utility of direct and indirect methods of transfusion, or the availability of transfusion sets. ${ }^{84}$ Several

\footnotetext{
appearance alters completely." (J. W. McNee, A. F. Sladden, and J. E. McCartney, op. cit., note 67 above, p. 33.)

${ }^{81}$ Bayliss's Oliver-Sharpey Lectures, delivered before the Royal College of Physicians in London, were published as Intravenous injection in wound shock, note 43 above, see esp. p. 20.

82 Bayliss to Cannon, 12 August 1918.

83 'Conference at Boulogne', note 79 above, p. 5.

${ }^{84}$ For a description of recommended procedures, see $A$ report upon transfusion of blood for the recently injured in the United States Army, pamphlet published by the Medical Division of the American Red Cross Society in Paris, France, May 1918. Cannon's name appears as a member of the committee making these recommendations. The list of supplies is pitifully inadequate by later standards; for example, only four plain glass bottles of one-litre capacity "marked 100 c.c., 400 c.c., and 700 c.c. at the proper levels" were recommended for each hospital.
} 
months later, the MRC in Great Britain re-evaluated the discussion at Boulogne on the basis of notes submitted by Bayliss and Dale and came to a conclusion that was completely different from that originally recorded in the minutes of the conferencenamely, "that in all cases of haemorrhage with shock, transfusion of unaltered blood or citrated blood is the best treatment yet available." 85

There was an afterglow to the meeting at Boulogne that warmed Cannon, especially the opportunity it gave him to say good-bye to those who had worked with him at Béthune, and to talk, perhaps for the last time, with Bayliss and Dale before leaving for home. One week later, he participated in an Interallied Surgical Conference at the Red Cross Research Society in Paris where matters in which he was especially interested, such as anaesthesia, shock, and transfusion, were discussed. "I and everybody else feels 'let down' and uninterested", he confessed to his wife soon after. "Life is flattened out. And only the excitement of going home again can revive us." 86 Nevertheless, out of a sense of obligation to the Red Cross, he not only attended all of the sessions of the conference but also stayed on for meetings of the Research Society. Both events, as he had anticipated, proved to be a repetition of all that he had heard before, and at their conclusion he was glad to return to Dijon.

In the days that followed, Cannon alternately worked on a history of the surgical laboratories ${ }^{87}$ and searched the mail room for his orders to return home. The wait was hard for him to bear. "I've had a troubled, depressing week", he began one letter in mid-December after a visit to Paris. “... I've tried distractions. I've looked up literature on shock. On Wednesday evening Fred [Murphy] and I went to the Comedie Francaise and saw some admirable acting of three plays by de Musset. Yesterday I went to Babinski's neurological clinics at La Pitie and got some insight into the permanent damage of the war-a poilu who had been shaking for two years since a shell burst near him, an aviator who had had a fall and was always dizzy, a young soldier with a wasted right arm - a few trifling examples of the war's wastage in human life." (LH, p. 509) The visit was yet another horror added to what Cannon had already experienced in the war.

\footnotetext{
${ }^{85}$ Minutes of special meeting, 24 March 1919, held at the MRC. In addition to Bayliss and Dale, the meeting was attended by Bainbridge, Laidlaw, Starling and Wallace. For later discussions of the case for and against gum-salt solutions, see Cannon, Traumatic shock, New York and London, Appleton, 1923, pp. 179-83, and Bayliss, 'Acacia for transfusion', J. Am. med. Ass., 1922, 78: 1885-7.

${ }^{86} \mathrm{LH}, \mathrm{p}$. 496. The proceedings of the surgical conference held on 22 and 23 November 1918 were published in War Med., 1918-19, 2: 1251-81 and reprinted as Chapter V in The Medical Department of the United States Army in the World War, vol. 11, Surgery, note 1 above, pp. 130-65. Although there was some support for gum acacia when blood was not available for transfusion, the tenor of the criticism concerning its use was much harsher at this conference than at Boulogne. For example, when many evacuation and mobile hospitals were asked for their opinions about acacia, there was scarcely a favourable reply; in fact, statements such as the following were heard: "Without any hesitancy I should say that gum salt solution is absolutely contraindicated." George Crile, a seasoned veteran, was one of the most critical and later wrote in his diary: "The physiologists were represented by ... Cannon. They had their day first. They sang the hymn of praise! Then the practical surgeons of the Argonne fight sang the swan song! Gum was condemned! Exit gum! Exit physiologists! Der Tag!" (quoted in English, op. cit., note 3 above, p. 205).

${ }^{87}$ LH, p. 498. Cannon's 'Historical record', note 60 above, was later incorporated into his chapter on 'Wound Shock', published in The Medical Department of the United States Army in the World War, vol. 11, Surgery, note 1 above, pp. 185-213.
} 


\section{Walter B. Cannon and the mystery of shock}

Several days later Cannon received a letter from Dale that buoyed his spirits, for it addressed a subject that was dear to his heart-the prospect of future collaboration between British and American medical scientists. "May I say once more", Dale wrote,

how much we have all valued your enthusiastic cooperation. It is especially pleasing to think that, after so much strenuous discussion, we come to what I suppose is the end of our formal association, without any material difference of opinion or attitude. I am sure that the effect of our association will be permanent in strengthening the feeling that we people on both sides of the Atlantic, who speak the same language, think along the same lines, have the same ideals and standards and understand the same jokes, must aim more and more at working together in essential matters like scientific investigation. People who can chaff one another without offence and differ without quarrelling are close colleagues, whatever their spatial or political separation. I am sure you agree. ${ }^{88}$

Cannon had hardly savoured Dale's letter when he learned that he was scheduled to sail for home on 11 January 1919.

In later years Cannon referred to his research on shock during World War I as "a parenthesis of war"-a digression from the natural progression of his ongoing investigations on the autonomic nervous system and the emotions. It was nevertheless a path he had voluntarily chosen. Cannon did not have to go to war; in 1917 he was fortyfive years old and the father of five. He could easily have stayed at home and worked experimentally in the safety and calm of his laboratory (as many other physiologists did) on the problems of the cause and onset of shock. Instead, convinced that these problems were too complex for immediate solution, he decided that it would be more useful to devise an effective therapy to aid wounded soldiers in shock.

Although Cannon's first clinical and laboratory investigations of shock in France and England raised expectations of a therapeutic breakthrough, they did not on closer examination fulfil their early promise. Later, however, building on the results of some of his collaborative research with British surgeons in the field, members of the MRC Shock Committee, and colleagues at the U.S. Army Surgical Research Laboratories, he developed a highly effective programme for training resuscitation teams and providing after-care that saved the lives of many shock victims in the final months of the war.

In 1923 Cannon published Traumatic shock, a volume that summarized the knowledge accumulated during the war, in the hope that it might provide new insights into the clinical phenomena of shock and the most effective way of treating it. While he continued to be interested in the subject and served as an advisor to young researchers in the field, he personally never investigated shock again. ${ }^{89}$

\footnotetext{
88 Dale to Cannon, 12 December 1918. The previous year, while in London in November 1917, Cannon had talked seriously with Dale about "the common heritage of our two peoples, their common interests, the similarity of ideals, and, with a few exceptions perhaps, the same taste in jokes". (LH, p. 195)

${ }^{89}$ See further Cannon, Traumatic shock, note 85 above; The way of an investigator, note 64 above, esp. pp. 130-45. In 1940, with America on the verge of entering World War II, Cannon had an opportunity to put his previous wartime experience to use when he became chairman of the Committee on Shock, Transfusion and Blood Substitutes of the National Research Council.
} 